\title{
Entrepreneurship in Technical Education Colleges: Applied Research on University College of Applied Sciences Graduates - Gaza.
}

Esmail A. M. Kassim*

The Islamic University of Gaza,

Gaza Strip, Palestine

Email: eqasem@iugaza.edu.ps

\author{
Allaa Khalil El Ukosh \\ Ministry of Transport, \\ Gaza, Palestine \\ Email: allaa.ukosh@hotmail.com
}

Received June, 2020; Accepted September, 2020

\begin{abstract}
The study aimed to examine the role of entrepreneurship dimensions (Degree of Risk, Entrepreneurial Culture, Creativity, Responsibility) in Technical Education and its dimensions (Trainer, Trainee, and Training Tools) as an applied study on graduates of University College of Applied Sciences in Gaza. The researchers used the descriptive-analytical method, and the total study population was 6373 graduates. The questionnaire was used a data collection tool, and a random sample method was applied. The sample consisted of 384 graduates with a recovery rate was of $91 \%$. The data were analyzed using SPSS statistical program. The study results showed that entrepreneurship dimensions impact positively dimensions of Technical Education in the University College of Applied Sciences. In addition, the weighted average of entrepreneurship dimensions in the college was about \%73.90, while the weighted average of technical education and training dimensions in the college was about $\% 72.40$.
\end{abstract}

Keywords: Entrepreneurship; Technical Education; Colleges; Training.

Type: Research paper
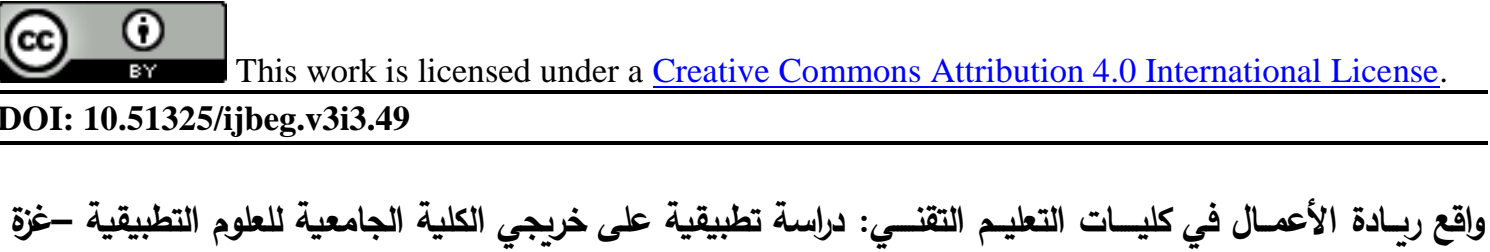

هدفت الدراسة إلى معرفة دور ريادة الأعمال بأبعادها (درجة المخاطرة، الثقافة الريادية، الابداع، المسئولية) في كليات التعليم التقني بأبعاده (المدرب، المتدرب، وسائل التدريب)، كدراسة تطبيقية على خريجي الكلية الجامعية للعلوم التطبيقية بغزة، وقد استخدم الباحثان المنهج الوصفي التحليلي، وبلغ اجمالي مجتمع الدراسة (6373) خريج، وكانت الاستبانة أداة جمع البيانات، وتم تطبيق أسلوب العينة العشوائية، وبلغت عينة الدراسة (384) خريج، وكانت نسبة الاسترداد (91\%)، وحللت البيانات باستخدام برنامج SPSS الاحصائي، وكان من أهم النتائج وجود أثر لأبعاد ريادة الأعمال بنحو 61.6\% في كلية التعليم التقني، وقد بلغ الوزن النسبي لواقع ريادة الأعمال في الكلية

$$
\text { الكلمو 73.90\%، بينما بلغ الوزن النسبي لأبعاد التعليم والتدريب التقني في الكلية بنحو } 72.40 \% .
$$




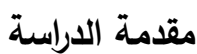

يتميز العصر الحالي بأنه عصر التكنولوجيا وذلك لتثعب استخداماتها في جميع مناحي الحياة، ويعتبر التعليم والتدريب التقني من أهم المجالات التي تأثرت بالتكنولوجيا الحديثة، من حيث انتاج وتثغيل وصنيل وصيانة الأجهزة التقنية المتطورة، وقد حرص القائمون على التعليم والتدريب التقني الى العمل على تطوير وسائل ومناهج التعليم التقني

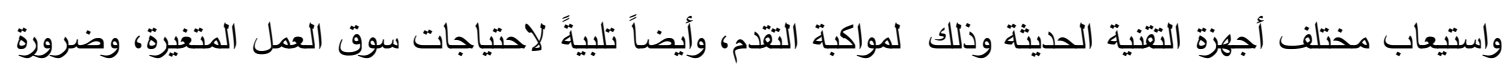
أن توفر تلك الكليات نوعية من الخريجين التقنيين مؤهلين على ملائمة التقدم والتطور التقني في جميع القطاعات

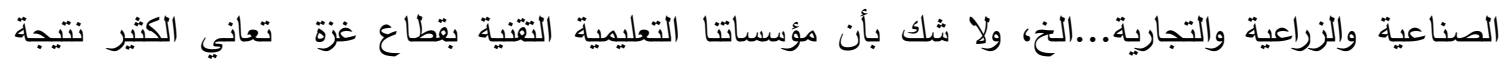

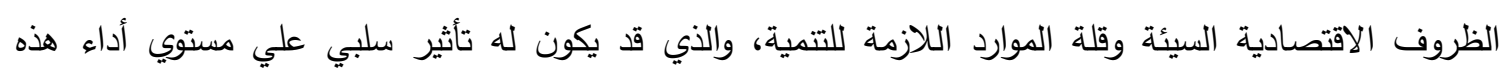

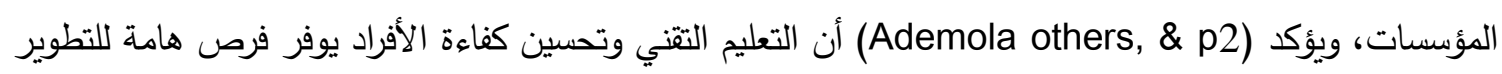
الاقتصادي، بينما يذكر (Ogundele,\& Oyelade, 2018, p1) أن التعليم المهني والتقني يؤدي دوراً حيويًا

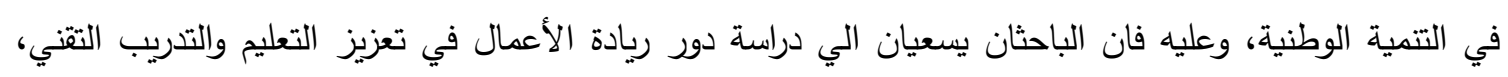

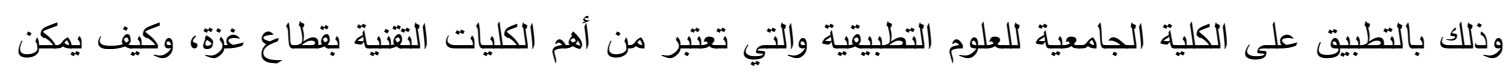
تطوير قدرات نوعية ريادية في المجال التقني، من خلال تحديث الوسائل التدريبية، وتوفير أحدث الوسائل التطبيقية

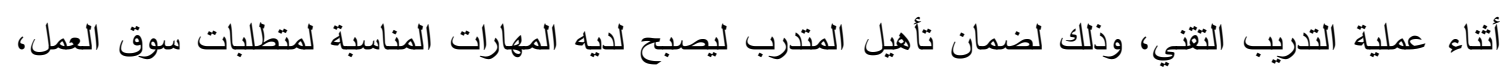

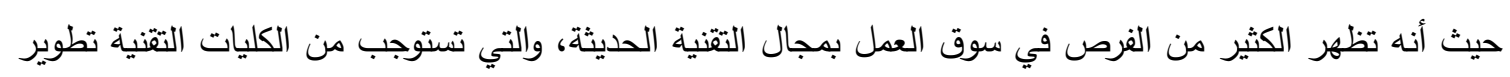
قدرات ملائمة في مجالات التدريب التقني وتطويره وأيضاً الاستفادة من أساليب ريادة الأعمال الحديثة.

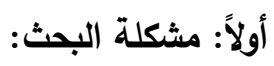

يواجه التعليم والتدريب التقني تحديات رئيسية نتيجة التحول المتسارع نحو استبدال الوسائل والأجهزة التقليدية بحديثة

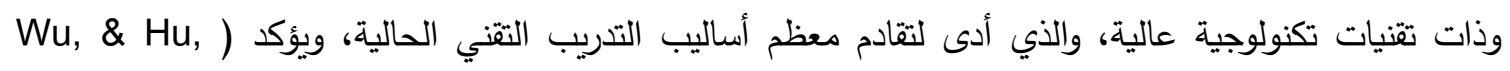
(2015, p2862 أن التوجه الحالي يتزايد نحو برامج التعليم الفني بدلاً من البرامج التعليمية العامة، ويوجد في ولئي

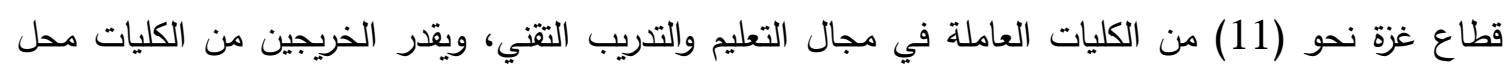

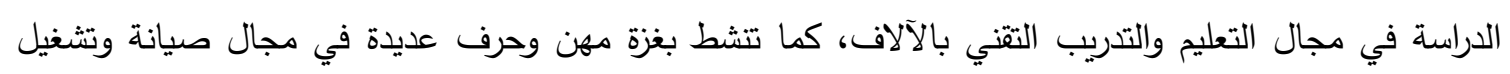

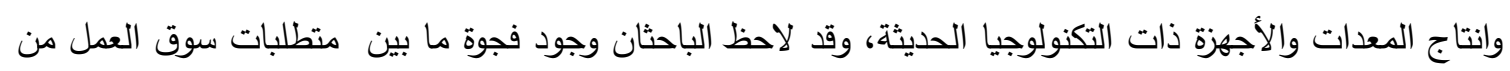
توافر مهارات تكنولوجية مميزة للراغبين في العمل التقني والواقع الحالي، وذلك في تدني مهارات الكثير من خريجي

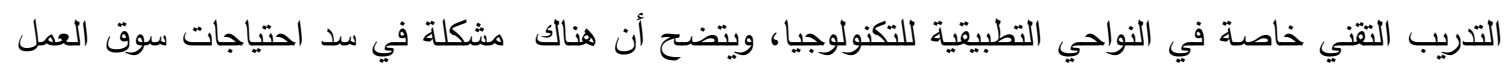

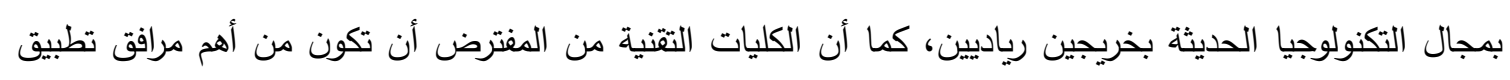

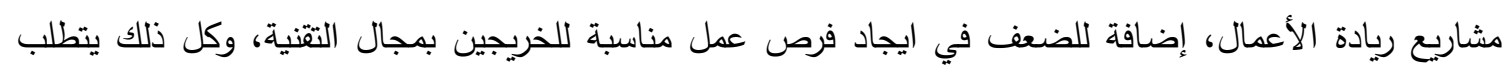

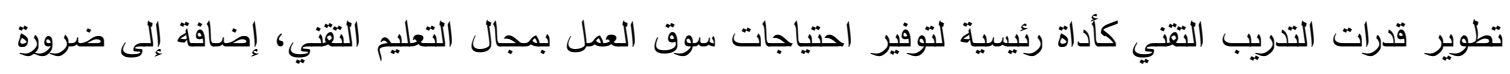

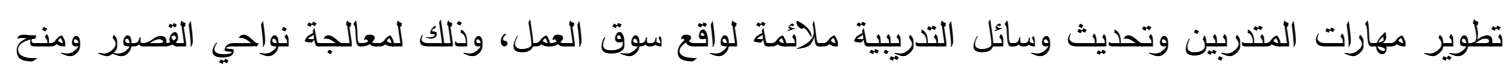
التدريب التقني ميزة تتافسية في سوق العمل، وبناء على ما سبق ذكره هل يمكن أن يكون لريادة الأعمال دور في

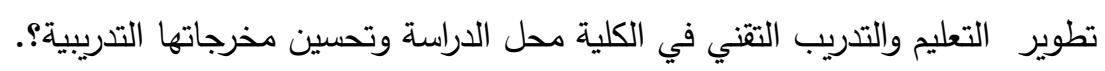
ويمكن صياغة مشكلة الدراسة في السؤال التالي:

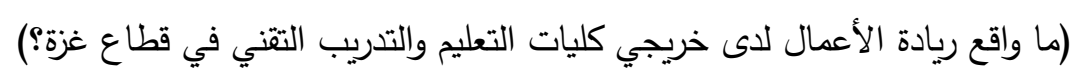


ويمكن اشتقاق عدة تساؤلات فرعية من السؤال الرئيس على النحو التالي:

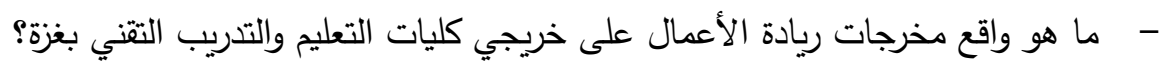

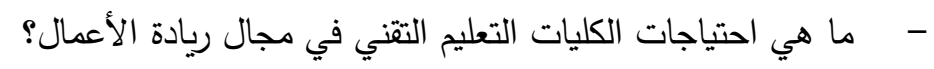

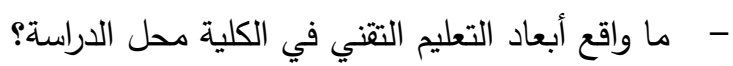

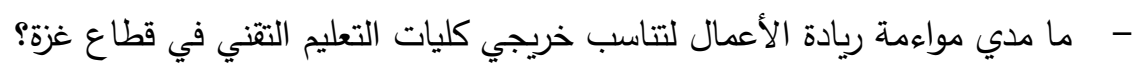
فروض البحث:

في ضَوِ مُشكلة وأهداف البحثِ يُمكن تحديد فرض البحثِ الرئيس فيما يلي: - - الفرض الرئيس: توجد علاقة ذات دلالة احصائية بين ريادة الأعمال وأبعادها (درجة المخاطرة، الثقافة

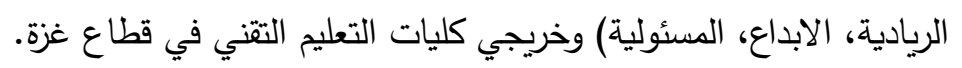
ويتفرع عنه الفروض التالية:

- - توجد علاقة ذات دلالة احصائية بين درجة المخاطرة وخريجي كليات التعليم التقني في قطاع غزة.

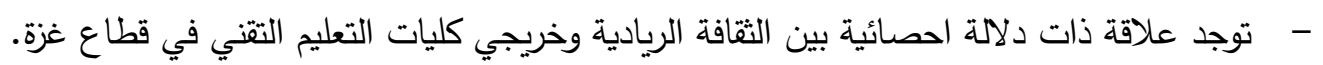

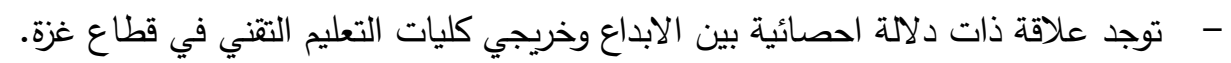
- - توجد علاقة ذات دلالة احصائية بين المسئولية وخريجي كليات التعليم التقني في قطاع غزة. الفرض الرئيس الثاني: يوجد أثر ذات دلالة احصائية لريادة الأعمال وأبعادها (درجة المخاطرة، الثقافة الريادية،

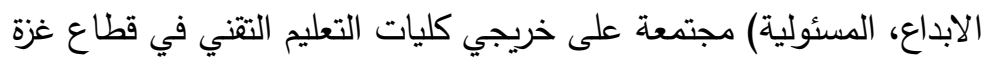
الفرض الرئيس الثالث: توجد فروق معنوية بين آراء المبحوثين حول ريادة الأعمال وخريجي كليات التعليم التقني في في في فئي قطاع غزة، وفقًا للعوامل الديمغرافية (الجنس، المؤهل العلمي، سنوات الخبرة، المستوى الوظيفي) الوكئ. أهداف البحث: - n

بعد إدراك أبعاد مشكلة الدراسة التي سعت لتقييم واقع ريادة الأعمال لدى كليات التعليم التقني بالتطبيق على خريجي الكلية الجامعية للعلوم التطبيقية في قطاع غزة وذلك للوصول للأهداف التالية:

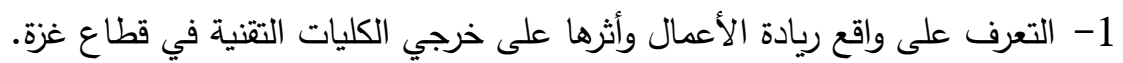
2- التعرف على دور ريادة الأعمال بأبعادها (درجة المخاطرة، الثقافة الريادية، الابداع، المسئولية)، وأثرها بمهارات خرجي كليات التعليم التقني في قطاع غزة. 3- الكثف عن واقع وأبعاد التعليم التقني بالكلية محل الدراسة.

4- التعرف على مدى ملائمة التعليم الريادي لاى كليات التعليم التقني في قطاع غزة. 5- الكثف عن الفروق بين آراء خريجي الكليات التقني عن واقع ريادة الأعمال تبعاً للمتغيرات الديموغرافية. أهمية البحث: ويمكن إبراز أهمية هذه الدراسة على النحو التالي:

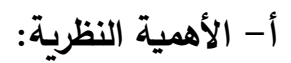
لوحظ انخفاض في الدراسات السابقة التي تتاولت ريادة الأعمال بأبعادها المفترضة بالدراسة الحالية وأثرها على خريجي كليات التعليم التقني في قطاع غزة مما أدى لتحفيز الباحثون على تتاول موضوع الدراسة بأبعاد مختلفة عن بأن الدراسات الموجودة و بذل مزيد من الجهود العلمية في هذا المجال، ومحاولةً للكثف عن العلاقات بين متغيرات الدراسة التي قد تسهم في اضافات عليمة وقيم جديدة تساهم في تطوير مجال ريادة الأعمال في التعليم التقني، 
وكذلك من الممكن أن تثجع الدراسة الحالية على وضع خطط عملية لتطوير أساليب ريادة الأعمال من مهارات تحمل أهمها تحمل المسئولية والمخاطرة والابداع والثقافة الريادية والعمل على تكييف برامج كليات التعليم التقني بها بهدف التأثير الايجابي في النواحي الريادية لاى خريجها، وتأصيل الاهتمام بها كقضية اقتصادية هامة تدعم

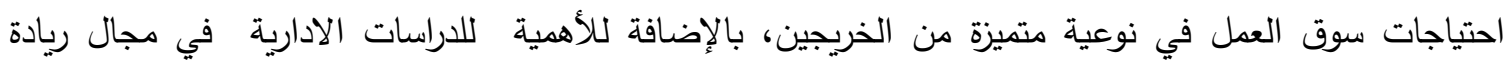

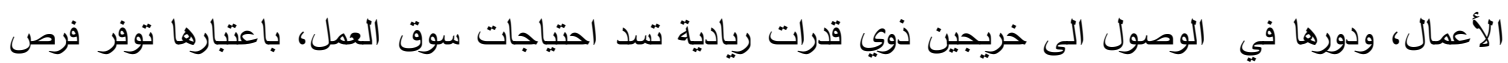
عمل كبيرة للخريجين في قطاع غزة. ب- الأهمية التطبيقية:

تم تتفيذ الدراسة على أهم وأكبر كلية للتعليم والتدريب التقني وهي الكلية الجامعية للعلوم التطبيقية بقطاع غزة، والتي لها دور رئيس في تقديم خدمات التعليم والتدريب التقني، وتعتبر من أهم كليات التدريب التقني بغزة ويمكن توضيح نقاط اضافية للأهمية التطبيقية للدراسة من خلامل فلات تخرج من الكلية محل الدراسة من العام 2015 -2019 نحو (6373) مهني في مجالات تدريبية في تقنيات حديثة تتاسب سوق العمل. الزيادة المتسارعة في فرص العمل بمجال تقنيات التكنولوجيا بقطاع غزة وضرورة تطوير تعليم تقني ريادي. توفير اقتراحات وتوصيات عملية لتنفيذ برامج تدريبية مهنية ذات كفاء عالية تتاسب سوق العمل بغزة. يعمل في مجال التدريب التقني بقطاع غزة (الآلاف) من العمالة ويقدر طلابها بالآلاف. تعد نتائج مثل هذه الدراسات أداة ومرجع هام في تحسين أداء الكليات التقنية بغزة. تساهم نتائج الدراسة في عرض الدور المفترض أن يؤديه ريادة الأعمال في تعزيز التدريب التقني. همكن أن تكثف نتائج تلك الدراسة عن نقاط القصور في التدريب التقني وكيف يمكن تطويره من خلال تعزيز

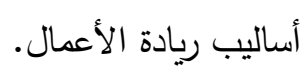
حدود الدراسة: ه الحد المكاني: خريجي الكلية الجامعية للعلوم التطبيقية في قطاع غزة. هـ الحماني: تتفذ الدراسة خلال الأعوام 2019-2020.

الحد البشري: عدد من خريجي الكلية الجامعية للعلوم التطبيقية في قطاع غزة. الحد الموضوعي: ايضاح واقع ريادة الأعمال لاى خريجي الكلية الجامعية للعلوم التطبيقية بغزة.

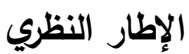

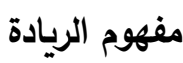

بدى الاهتمام المحلي والعالمي واضحاً في مجال ريادة الأعمال، كمحور اداري يعزز التتمية الاقتصادية، وذلك من خلال مشاريع ابداعية وأفكار ابتكارية ممكن تحويلها الى مشاريع ذات قيمة مضافة للاقتصاد المحلي، وقد تم ذكر العديد من لمفاهيم الريادة فقد عرف أول شخص أدخل مصطلح الريادة (Richard Cantillon) يتحمل المخاطر والتعامل مع الظروف والحالات غير الواضحة، والقدرة على إدارة ملكية المشروع للحصول على الأرباح، واستغلال رأس المال وتوظيفه بكفاءة في العملية الإنتاجية (المبارك، 2009)، بينما ذكر الحسيني (2006) أن الريادة هي

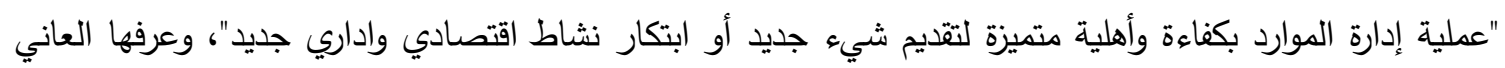

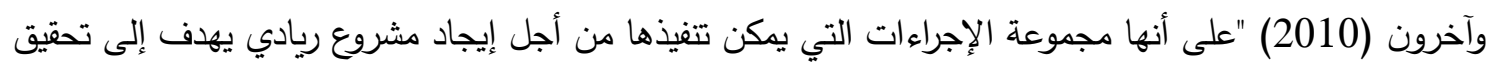

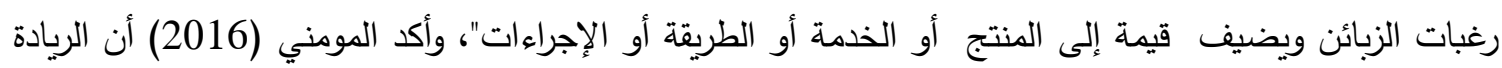

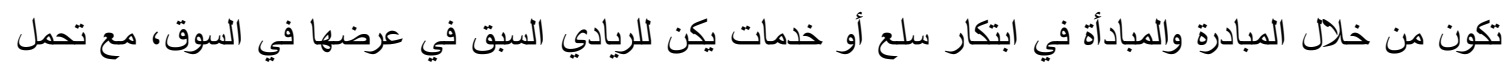


المخاطر، بينما يذكر زيدان وخليل (2017) أن الريادة تتحقق في النجاح بمواجهة في التهديدات، وهكذا يصبح

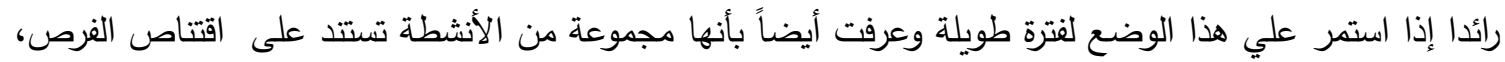

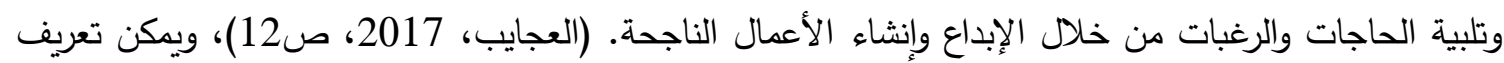

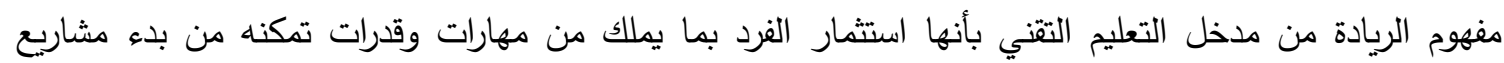

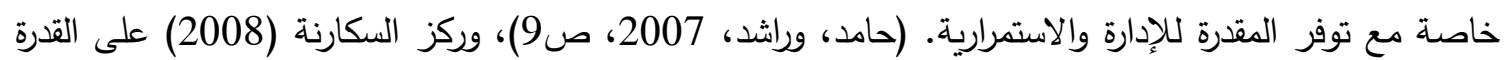

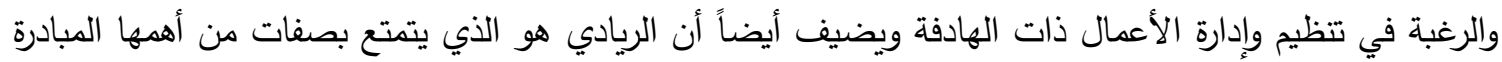

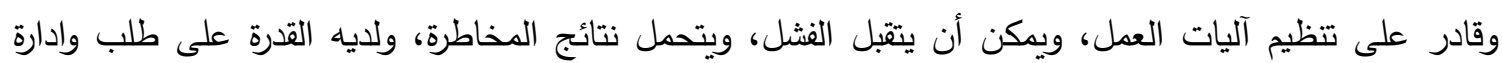

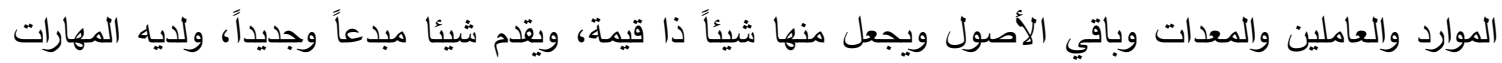
والخصائص سواء الإدارية والاجتماعية والنفسية التي تمكنه من ذلك. ولك. - أهمية ريادة الأعمال تساهم ريادة الأعمال بثكل أساسي في عملية التتمية، وانجاز الكثير من الأهداف الاقتصادية والاجتماعية، والتي تتصل في توفير فرص عمل واستحداث أنشطة اقتصادية جديدة (المخيزيم، 2017)، ويذكر (أبو هديب، ونية 2017) أن من أهم أهداف الريادة تحقيق الارباح والاستقلالية في العمل، بينما يرى كل من زيدان وخليل (2017) ودياب (2012) أن الريادة توفر فرص لابتكارات جديدة هامة للمنافسة والتميز وخدمة المجتمع بكل قطاعاته. - تصائص المنظمات الريادية تنفرد المنظمات الريادية في العديد من الخصاص التي تميزها في مجال عملها ويمكن على أساسها أن تصنف تلك المنظمات بأنها ريادية ومن أهم تلك المواصفات ما يلي: - توافر أفراد رياديين لن يكون هنالك إبداع من دونهم. - عمق البعد التتظيمي المرتبط بالرؤية، الثقة، المثالية، الإبداع، التحوط للفشل، التحوط للغموض، الرقابة الداخلية. - البعد البيئي خاصة بالتتوع بالأسواق.

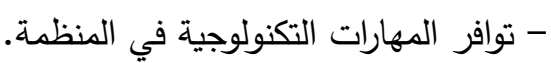

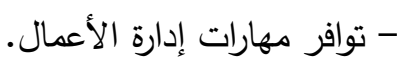
- المهارات الريادية الثخصية (السكارنة، 2008). - القدرة على المخاطرة المعتدلة كمهارة وليس كمجازفة (خربوطلي، الربادية 2018). - القدرة على الاستفادة القصوى من الموارد المتاحة (الحمالي، والعربي، 2016). - الابداع والابتكار وهي قدرة المنظمات على تحويل الأفكار الى منتجات وخدمات جديدة (عبد الوهاب، 2018) - سمات رائد الاعمال: - وصف David Me Celland رائد الأعمال بأنه شخص تحركه الحاجة لإنجاز شيء ورغبة كبيرة في اضافة جديدة. - بينما حدد Moor \& Collins صفات الثدة والصمود للرواد حيث تدفعهم مصالحهم للإنجاز . - يرى Barney \& Busenitz أن رواد الأعمال يتميزون بالثقة الثديدة بالنفس وتعميمهم الزائد للأمور .

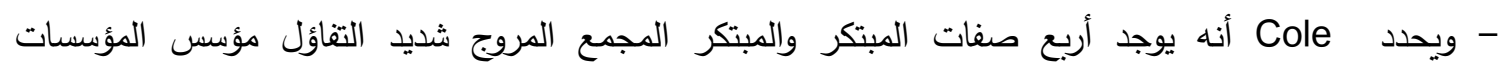
(الخربوطلي، ونان 2018)

- توافر لدى الرائد مهارات الاتصال والتشبيك وادارة التكنولوجيا الحديثة (2015) European Commission. - التعليم للريادة أو التعليم الريادي: 
يعتبر التعليم الريادي من أهم استراتيجيات الحد من بطالة الخريجين فئة الثباب، حيث يوفر هذا التعليم المعارف والمهارات التي تساعد على ايجاد فرص عمل او انثاء مشارع صغيرة (مهناوي، 2014 ), وقد عرّف لهن السيد

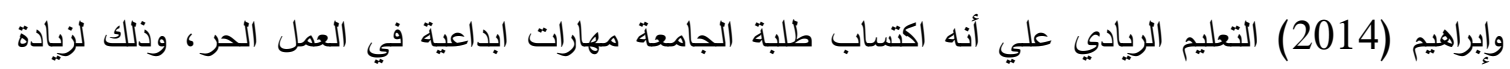
الوعي بإدراك الفرص الوظيفية، وجعل الخريجين مساهمين في التتمية المجتمعية، سعياً لعلاج مشكلات البطالة والفقر والعنف، بينما كما عرفه أبو الثعر ( 2016) بأنه تعزيز الثقة بالنفس وتغذية المواهب الإبداعات الفردية، وبناء القيم والمهارات ذات العلاقة، والتي ستساعد الدارسين في توسيع مداركهم من خلال الدراسة، كما أشار مبارك (2014) إلي أن نشر التعليم الريادي يوفر فرص توظيف جديدة، ويرى كل من الحمالي والعربي (2016)

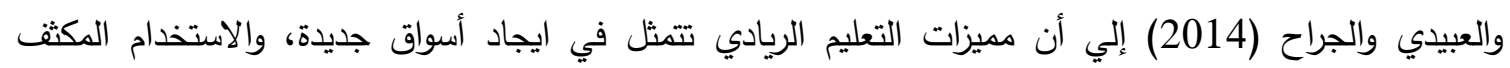

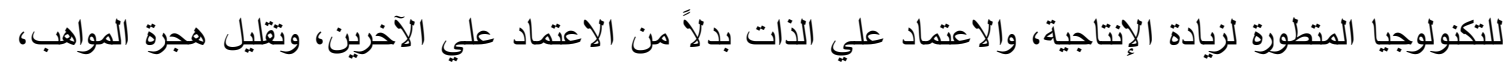

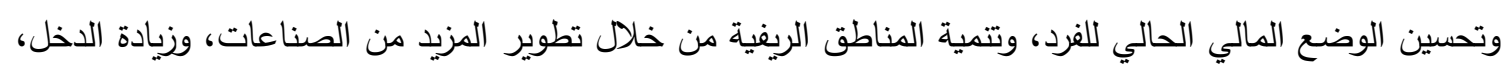
وزيادة النمو الاقتصادي.

- دور المؤسسات الأكاديمية في تعزيز الثقافة الريادية: أثرت ريادة الأعمال على مسار عمل الجامعات خاصة التي تسعي لزيادة قدرتها التتافسية، والتوسع في برامجها

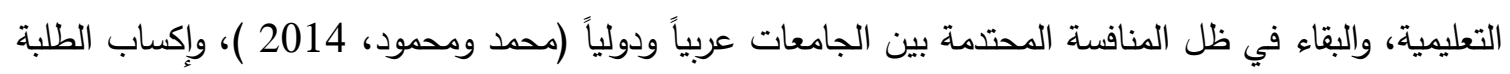
المهارات الريادية يستوجب من الجامعات بذل المزيد من الجهود لإكسابهم مهارات، تأهيلهم نفسياً وفكريا للبدء في العمل الحر (Alareeni, 2018 ;سلطان، 2015)، لذلك فقد اعتمدت العديد من الجامعات العالمية بعض البرامج التعليمية والمقررات الدراسية في ريادة الأعمال، وتوجهت الكثير من المؤسسات الحكومية والخاصة إلي إعداد برامج

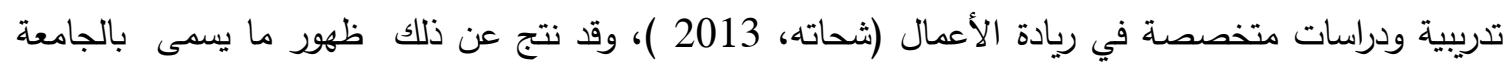

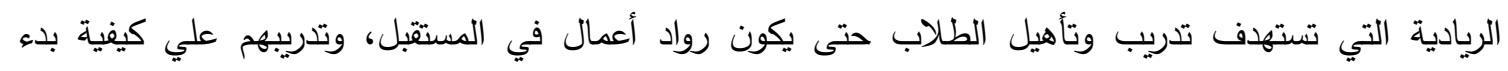

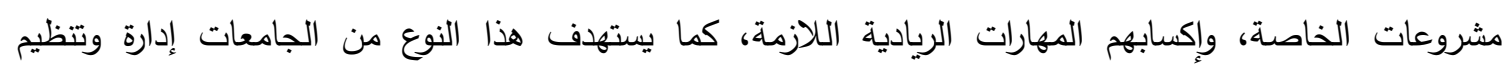
ومشاريعهم بطريقة ريادية، وتقديم المساعدات المالية لهم (محمد ومحمود، 2014 ). مفهوم التعليم ولتدريب التقيني يعد التعليم والتدريب التقني من أهم محاور التعليم باعتباره أحد أهم الدعائم الاقتصادية للدول التي تسعى للتطور، التئي

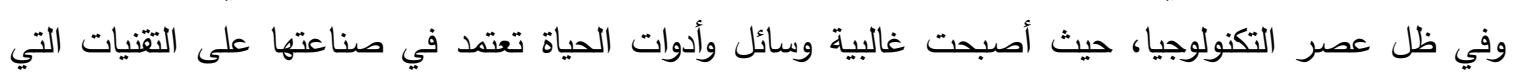
تؤسس على أفكار ريادية، ويمكن عرض مفاهيم التعليم والتدريب التقني على النحو التالي:

- التعليم التقني

تم تتاول بعض مفاهيم التعليم التقني من النواحي النظرية التي تثمل عرض لنظريات التعليم التقني ومفاهيمه

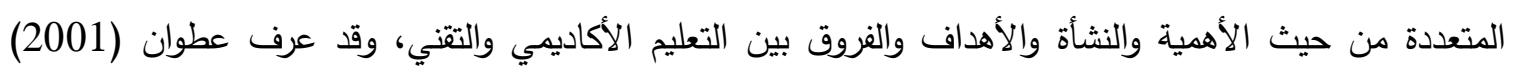

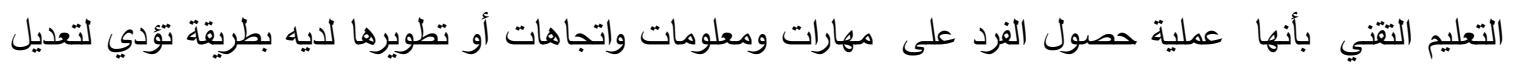
أدائه ليصبح قادراً على تتفيذ جزء من العمل أو بعمل متكامل وبشكل مناسب، وتشمل الاعداد لتلك البرامج لتأهيله

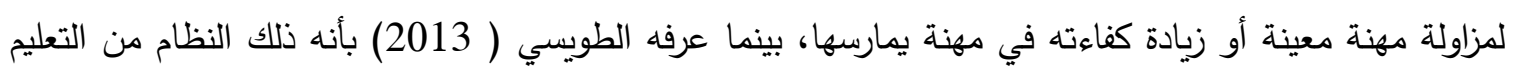

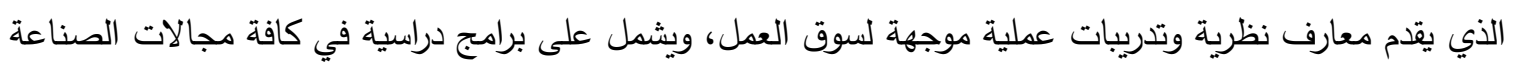

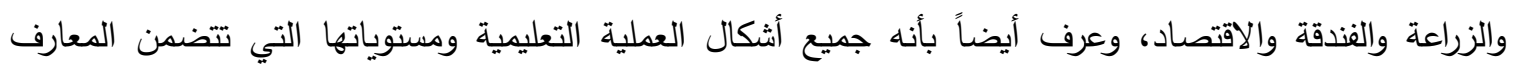

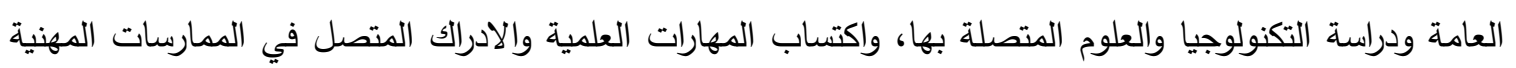

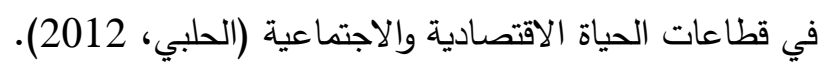




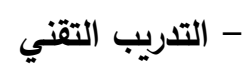

يعتبر التدريب التقني أنه الجانب العملي والميداني في عملية التعليم التقني، والذي يركز أكثر على تلقين واكساب

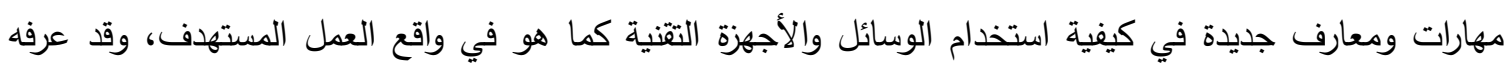
العاجز (2008) أنه نوع من أنواع التعلم الذي يتضمن مجموعة من المهارات والقدرات الفنية والتوجيهات السلوكية

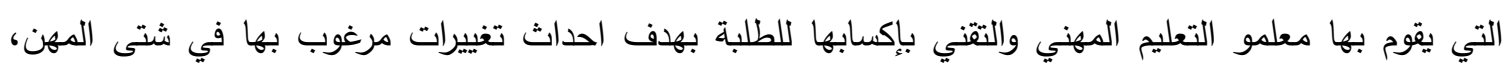

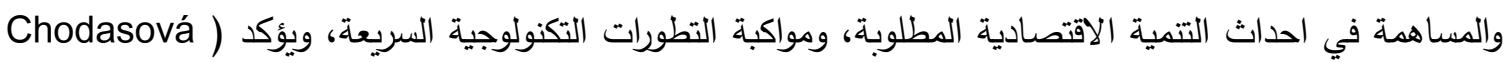
(et al., 2015

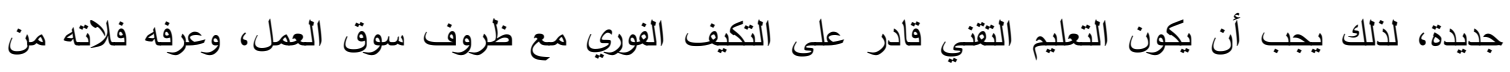
المدخل التدريبي على أن التدريب المهني هو النشاط المتسم بالصبغة العملية باكتساب المتدرب مهارات محددة في في في فئي

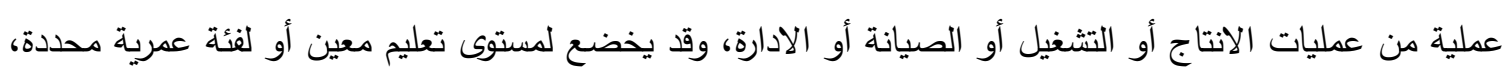
أو لفترة زمنية معينة (أبوعصبة، 2005). وبعد عرض عدد من المفاهيم التي تناولت التعليم والتتريب التقني فانه يمكن للباحثين اقتراح تعريف للتعليم التقني

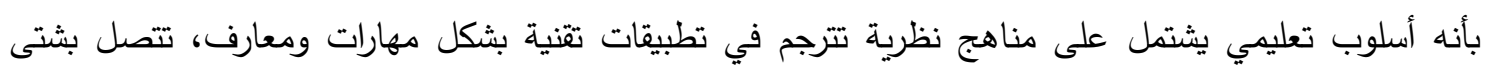

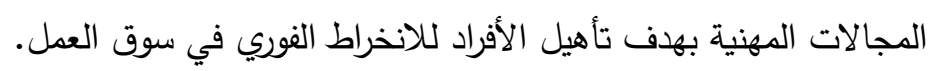
- أهداف التعليم التقني

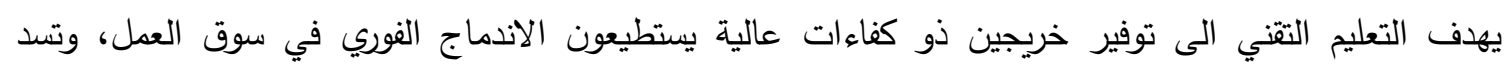

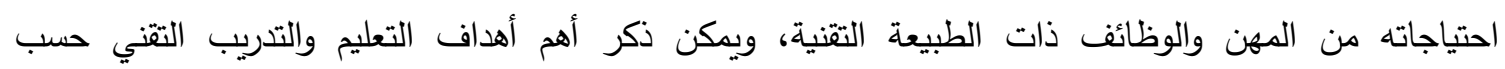
(أبوعصبة، 2005) كما يلي: 1. تتمية الاتجاهات الايجابية لدى المتدربين كقيمة رئيسية التي يستمد منها المجتمع توجهات نموه وتطوره. 2. مقابلة احتياجات المجتمع من العاملين وتلبيتها بمعناهما الواسع من العمالة الماهرة. 3. العمل على تلبية حاجات العمال من حيث الوعي والادراك لكل جديد ليكونوا أكثر تأهيلاً. 4. اكساب الفرد المعارف الملائمة لتخصصه وفق الأسس والمعايير المقبولة في سوق العمل (حماد، النخالة، . $(2008$ 5. تزويد المجتمع بالقوى العاملة الماهرة والمؤهلة، ومواكبة التطورات العلمية والتكنولوجية الحديثة (المحاريق، . (2014

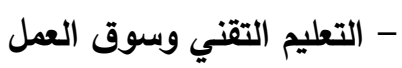
يوفر سوق العمل الكثير من الفرص في مجالات أكاديمية ومهنية ضمن القطاعات الاقتصادية، وقد حدث تحول كبير نتيجة الزيادة المستمرة في طلب مهن تقنية خصوصاً بعد الانتشار الواسع وفي شتى المجالات لوسائل وأجهزة تعمل بواسطة تكنولوجيا حديثة، وما يتطلبه ذلك من صيانة وتشغيل ويمكن عرض توجهات التعليم التقني كما يلي:

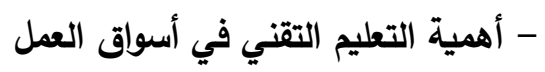
أصبح سوق العمل الركيزة الأساسية في توفير فرص عمل مناسبة لخريجي الكليات التقنية حيث يذكر (العجوري،

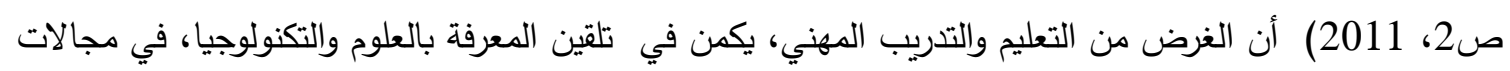
مهنية واسعة وتنمية الكفاءات التقنية والمهنية المطلوبة، ويعتبر التدريب التقني من أهم حلقات الوصل بين التين النظام 
التعليمي وسوق العمل، ويؤكد (Mahajan\& Golahit, 2017) أن هناك نمو سريع للتعليم التقني في العقد الماضي من حيث المؤسسات والقدرة الاستيعابية, كما يرجع اللامي, النعيمي (2003) أن التطورات السريعة في

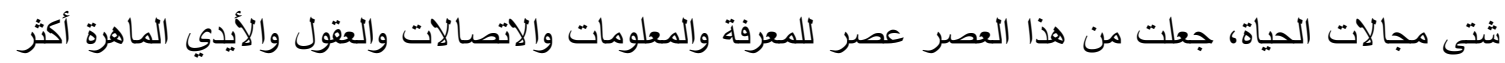
من الاعتماد على رأس المال، وقد عززت تلك التحولات من أهمية التعليم والتدريب المهني والتقني، ويرى (2018 أن هدف التعليم التقني تزويد الطلاب بالتدريب التقني في مجالات مهنية محددة، والتدريب العام (Rosen et al., لإعدادهم لسوق العمل، ويذكر (Anke \& Agnes, 2019) أن مؤسسات التعليم والتدريب المهني قائمة على توفير

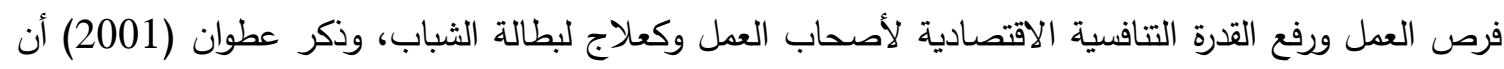

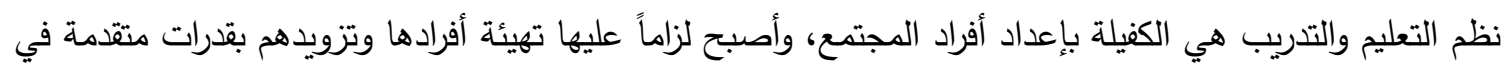

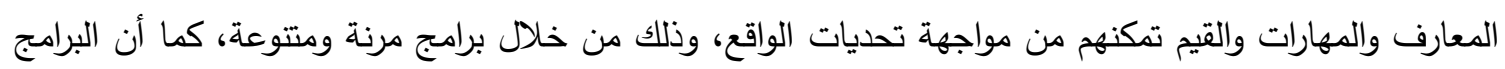

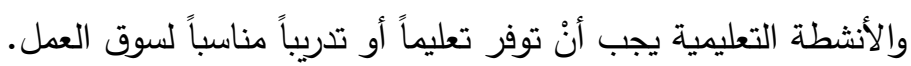
- التعليم التقني وتوفير فرص العمل تعاني أسواق العمل في فلسطين من ركود اقتصادي وتدني في فرصني فرص العمل المتاحة بشكل عام، نتيجة السياسات

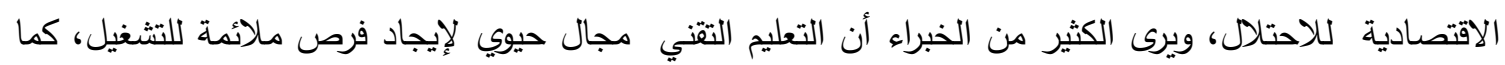
يذكر المحاريق (2014) أن التعليم التقني الموجه نحو مهارات حياتية والتي تثمل على كفايات أساسية للمتطلبات التكنولوجية والاجتماعية هو ضروري عند المشاركة في أدوار منتجة ضمن مجتمعات دائمة التغيير، ويرى أحمد (

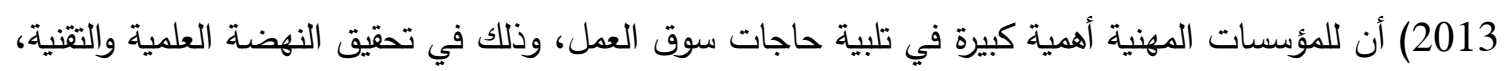
وباعتبارها أيضاً مصدراً رئيسياً لإعداد العمالة المؤهلة، والتي يحتاجها المجتمع في التتمية الاجتماعية والاقتصادية والثقافية، وفي مواجهة التحولات والمتغيرات العلمية والتكنلوجية الحالية والمستقبلية.

\section{- التعليم التقني وتطوير سوق العمل موافهان}

ساهم التعليم التقني في تطوير جوهري في سوق العمل خاصة في الدول النامية، والتي اضطرت الى مواكبة التغيير

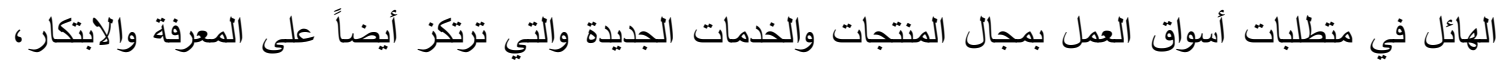

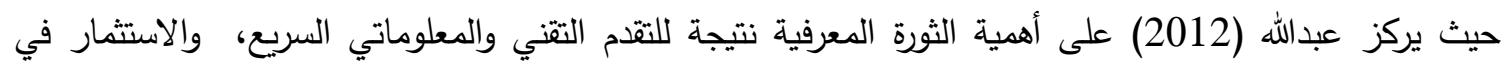
تتمية رأس المال البشري كركيزة أساسية لتحقيق التتمية الثاملة، وذلك من خلال التركيز على الفرد المتعلم القادر على التوافق مع هذا التقدم العلمي والتقني وتغييراته المستمرة، والمساهمة في عمليات الإبداع والابتكار، حيث ميثل يمثل

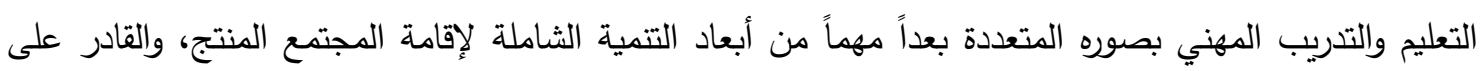
المنافسة في ظل النظام العالمي الذي تحكمه آليات السوق واقتصاداته، حيث تتبهت المجتمعات الصناعية لهذه

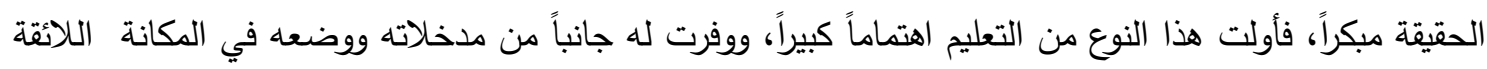
به، ويري المولى (2012) أنه تتتشر في معظم البلدان العربية ظاهرة عدم الموائمة ما بين مخرجات التعليم والتدربب التقني واحتياجات سوق العمل وتزداد خطورةً واتساعاً، وبرزت هذه الآثار في بطالة متزايدة وانتاجية منخفضة، وضعف في القدرة التنافسية واعتماد متزايد على المهارات الأجنبية، ويذكر بدرخان(2014) أن التعليم المهني يحتل مكانة هامة في السياسات التربوية للدول المتقدمة والنامية كافة، لما يوفره من مزايا كثيرة في النظام ولثرام

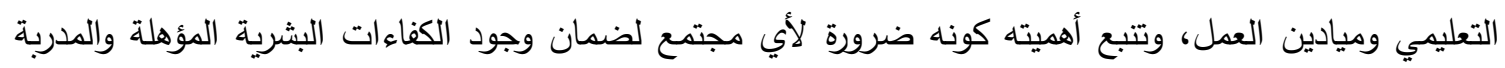

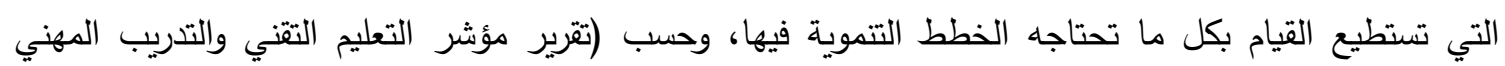

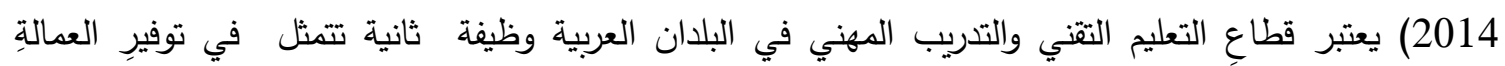
المعرفية من المستويات الوسيطة التي يحتاج إليها اقتصاد المعرفة، وذلك لمواجهة تحديات العولمة المتمثلة في 
تحييدِ آثارِها السلبية والاقتصادية والاجتماعية، ورفعِ القدرات على تطبيق المعارفِ المهنية المكتسبة في مسارات الإنتاج المختلفة، بما يؤدي إلى تحسينِ المواءمة بين العرض والطلب خاصة في مجالاتِ الاقتصاد الجديد. الاراسات السابقة

(Anderson, et al., 2020) دراسة

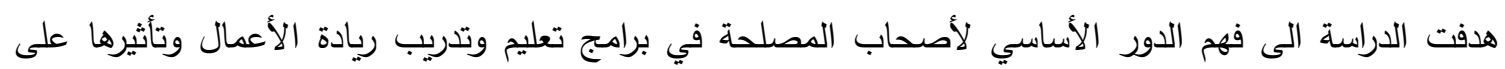
تتمية الإقليمية واعتمد البحث على أسلوب المقابلات مع مختلف أصحاب المصلحة المشاركين في برنامج تعليم وتدريب ريادة الأعمال في البرتغال, وأظهرت النتائج أن المشاركة الفعالة لأصحاب المصلية المصلحة في برامج ريادة الأعمال مهمة لضمان استدامتها، واتضح أن إنشاء شبكة بين أصحاب المصلحة هام وأساسي لضمان مزيد من

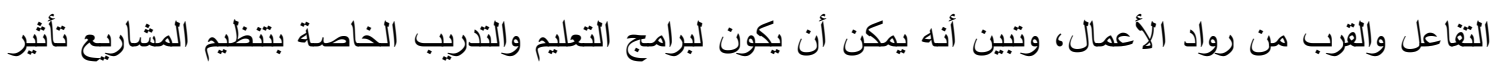

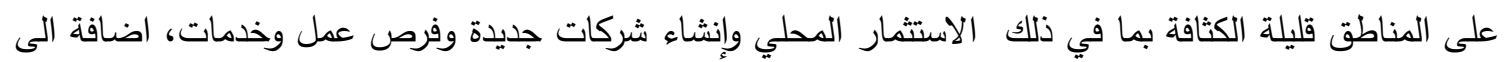
أنه من المتوقع أن تكون تلك النتائج بمثابة حافز للحكومات لوضع سياسات عامة تشجع على تتظيم المشاريع وبرامج التعليم ذات الصلة، وتبرز النتائج أيضاً الحاجة إلى إشراك أصحاب الصدابة المصلحة الإقليميين المختلفين في برامج ريادة الأعمال التي تولد أعمالًا جديدة لها تأثيرات إيجابية على التتمية المحلية والإقليمية.

(Alcaraz,et al., 2019) دراسة

سعت الدراسة لتتفيذ بحث تطبيقي على شركة متوسطة الحجم تهتم في إنثاء برامج تركز على قطاع الصناعة (مثل السياحة وصناعة الاتصالات) وتدعم الحلول الثاملة لتعزيز تلك القطاعات، وصولاً الى تحليل العوامل

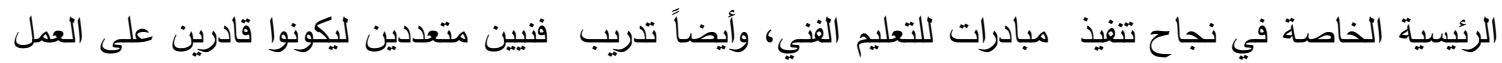

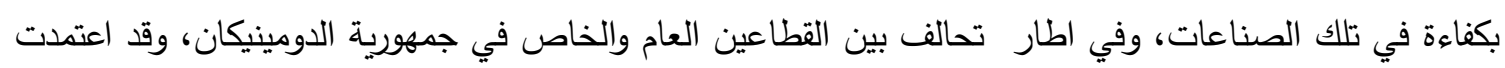

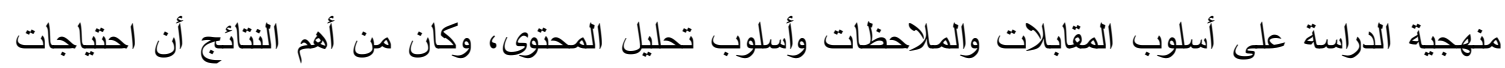
التعاون ما بين القطاعين الخاص والعام يتطلب إيجاد استراتيجية تتافسية قوية تعتمد على الفنيين المؤهلين القادرين

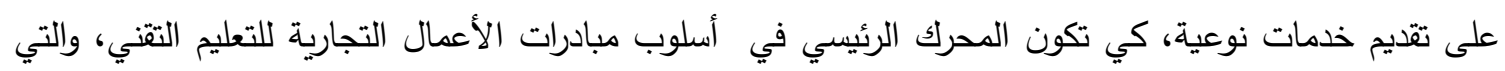

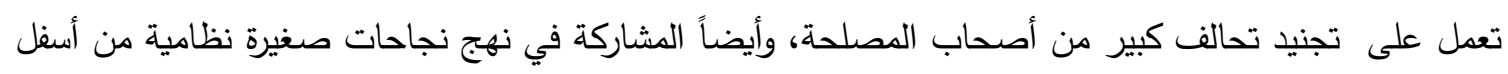
إلى أعلى، وقد ينتج عن هذه المبادرات فوائد اقتصادية كبيرة للشركات وتغيير جوهري للجوانب الأساسية للتعليم

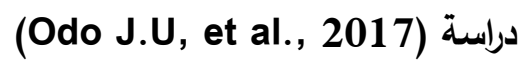

سعت الدراسة الى التعرف على دور التعليم التقني كواحد من أكثر وسائل تنمية الموارد البشرية فعالية، ومناقشة ندرة القوى العاملة الفنية الماهرة في نيجيريا وتأثيرها على التطور التكنولوجي، وتعزيز شراكة القوى العاملة اللازمة لتطوير مناهج للتدريب التقني، ودور المجتمع والحكومة والأفراد، وكان من أهم نتائج الدراسة أن التعليم التقني يمكن فئن

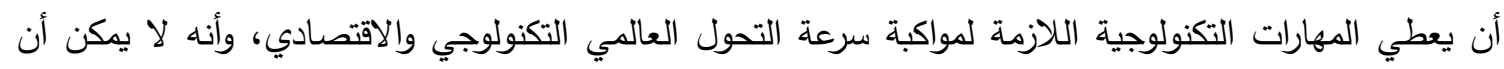

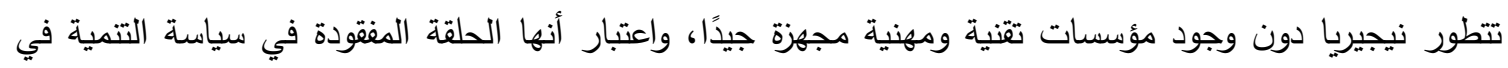
نيجيريا، بسبب سوء التدريب والمؤسسات الفنية غير الفاعلة، كما أنه لا يمكن تحقيق ذلك إلا من خلال إحياء التعليم التقني بالكامل في نيجيريا، مع ظهور أنشطة قوية وحيوية ذات توجه تتموي وتكنولوجي، ومطلوب من

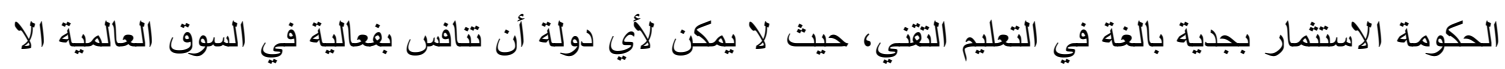

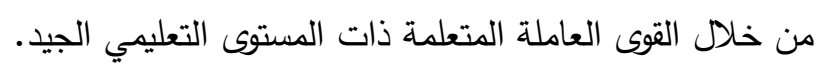
دراسة (الشمسي، 2017) 
هدفت الدراسة الى تثخيص واقع التدريب والتعليم والمهني في اليمن، وتحليل العلاقة بين مدخلات التعليم والتدريب

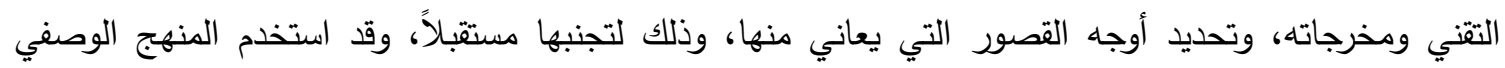

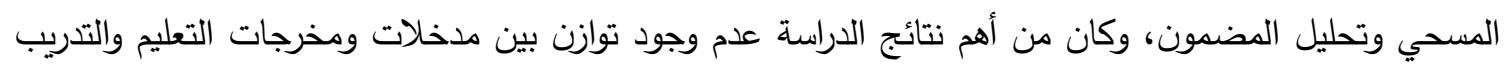
التقني والمهني ومتطلبات التتمية، اضافة لغياب استراتيجية ورؤية واضحة لتحديد أهمية هذا النوع من التعليم الوسطي (المهني) والتعليم العالي في تحقيق استراتيجيات التطوير والتتمية.

دراسة (Badariah, 2016)

الغرض من هذه الدراسة هو تقييم فعالية برامج تعليم ريادة الأعمال على بعض طلاب الجامعات الماليزية ومعرفة

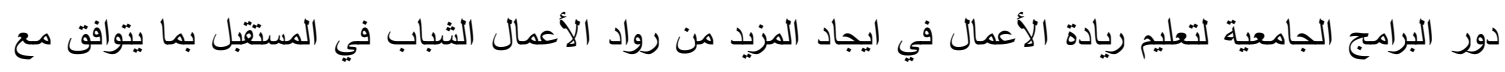
أهداف البرامج الريادية وتحديات العالم الخارجي, وقد استخدمت الدراسة أسلوب المسح الثامل لتثييم فعالية برنامج

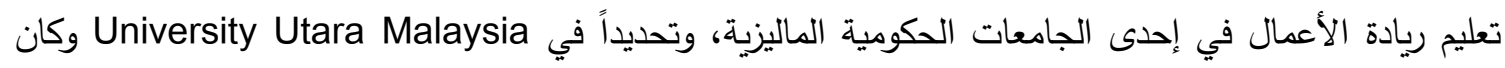

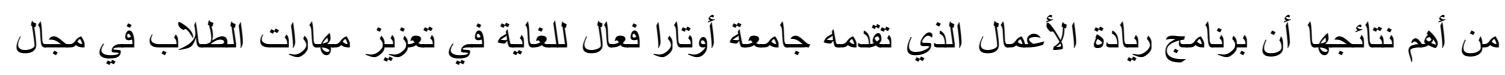
تتظيم وتتفيذ المشاريع الريادية، ووجود علاقة قوية بين خطة العمل والتفكير في المخاطر ، وكذلك الكاني الفعالية الذاتية وفعالية البرنامج، وممكن أن تقيد نتائج الدراسة صانعي السياسة حول كيفية اتخاذ التدابير المناسبة فيما يتعلق

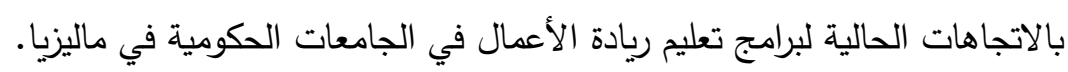

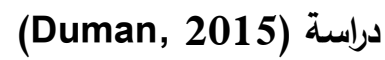
سعت الدراسة الى تحديد العوامل التي تؤثر على ريادة الأعمال في المشاريع المتوسطة والصغيرة والتعرف على الصى

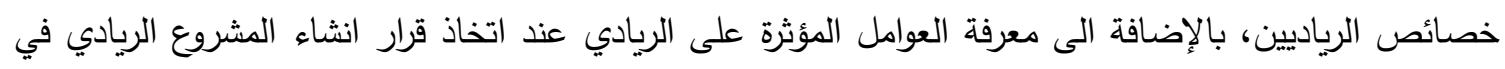

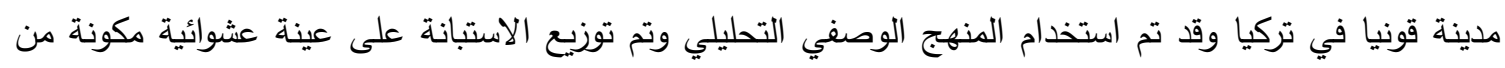

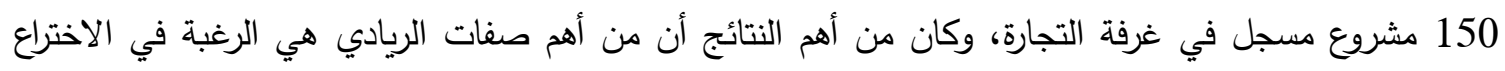

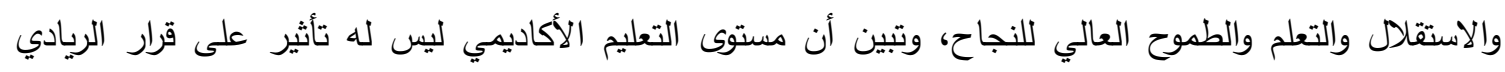
لإنشاء المشروع. واستفاد الباحث من تحليل الاراسات السابقة على النحو التالي: استطاع الباحث من خلال تحليل الدراسات السابقة تحديد وتثخيص أكثر دقة لمظاهر مشكلة الدراسة، وصياغة أفضل للفروض وتحديد دقيق للأهداف، وكذلك اختيار أهم الأساليب الاحصائية المناسبة، وايضاح طبيعة الاختلاف

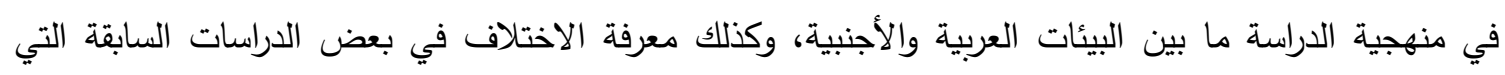

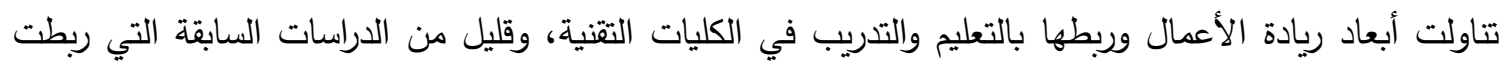
بثكل عميق ما بين بعض أبعاد ريادة الأعمال والتعليم والتدريب بكليات التعليم التقني كما جاء بالدراسة الحالية. المنهجية الاجراءات تعتبر منهجية الدراسة وإجراءاتها محوراً رئيساً يتم من خلاله انجاز الجانب التطبيقي من الدراسة، وعن طريقها يتم

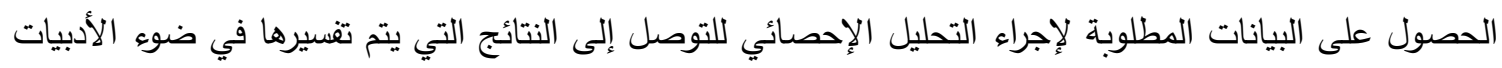
المتعلقة بموضوع الدراسة، وبالتالي تحقيق الأهداف التي تسعى الدراسة إليها.

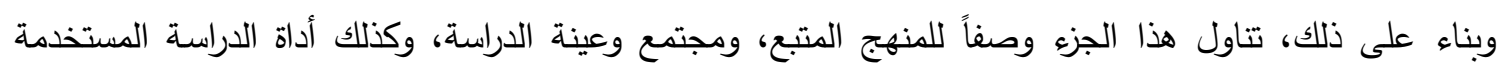

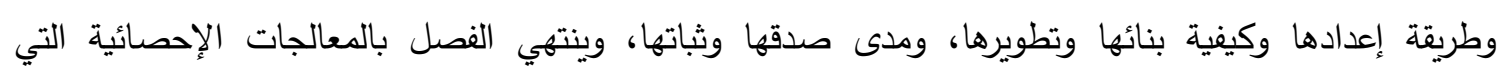

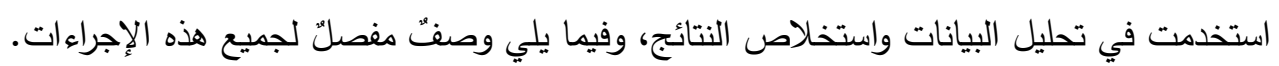


أولاً: منهج الدراسة:

من أجل تحقيق أهداف الدراسة قام الباحث باستخدام المنهج الوصفي التحليلي الذي يحاول من خلاله وصف الظاهرة موضوع الدراسة وصفاً دقيقاً، والتعبير عنها كيفاً وكماً، وذلك من خلال تحليل بياناتها، ودراسة العلاقة بين مكوناتها والآراء التي تطرح حولها والعمليات التي تتضمنها والآثار التي تحدثها. ثانياً: مصادر الدراسة:

لقد استخدم الباحث مصدرين أساسيين للمعلومات وهما: 1. المصادر الثانوية: حيث اتجه الباحث في معالجة الإطار النظري للدراسة إلى مصادر البيانات الثانوية، والتي التي

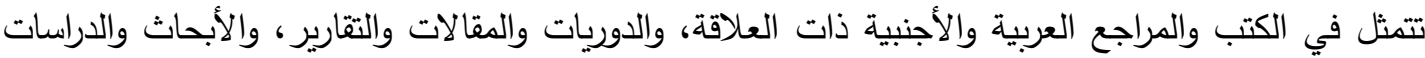
السابقة التي تتاولت موضوع الدارسة، والبحث والمطالعة في مواقع الإنترنت المختلفة. 2. المصادر الأولية: لمعالجة الجوانب التحليلية لموضوع الدراسة لجأ الباحث إلى جمع البيانات الأولية من خلال

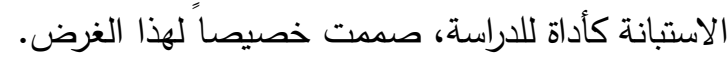

ثالثاً: مجتمع الاراسة: يتمثل مجتمع الدراسة بجميع الخريجين من الكلية الجامعية للعلوم التطبيقية والتي تعتبر أكبر كلية للتعليم والتدريب التقني بقطاع غزة من الفترة (2015 -2019) وبلغ اجمالي مفردات مجتمع الدراسة (6373) خريج (المصدر مركز معلومات الكلية الجامعية للعلوم التطبيقية بغزة، فبراير 2020). رابعاً: عينة الدراسة:

اختار الباحثان تحديد حجم العينة حسب عدد من أهم معادلات الاحصاء التي تحدد أفضل حجم لعينة ضمن مجتمع يعد مفرداته بالآلف والتي تفترضه بأن يكون (384) مفردة، كما أن الكلية محل الدراسة لديها مركز للخريجين لمتابعة شؤنهم وتستخدم وسائل تواصل تكنولوجيا متقدمة مع خريجها، وبناء عيله استغل الباحثان تلك بكان

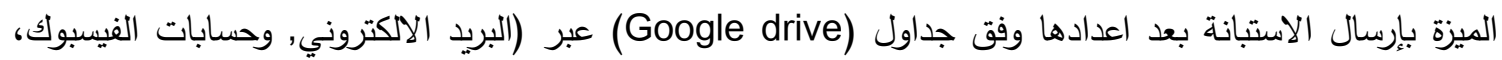
والواتس أب) وقد تم توسيع حجم العينة لتصل لنحو 400 استبانة الكترونية وقد تم استرداد نحو 364 استبانة بنسبة (91\%) صالحة لشروط التحليل الاحصائي. - العينة الاستطلاعية: تكّونت عينة الدراسة الاستطلاعية من 30 مفردة، تم اختيارهم بطريقة عشوائية بغرض تقييم

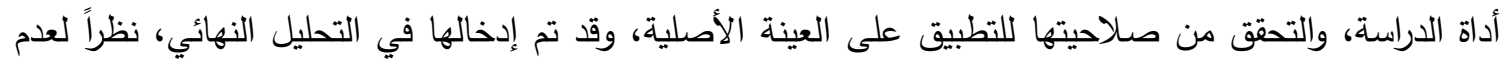
وجود خلل في الصدق والثبات. خامساً: أداة الدراسة:

تم إعداد استبانة حول "واقع ريادة الأعمال في كليات التعليم التقني: دراسة تطبيقية على خريجي الكلية الجامعية

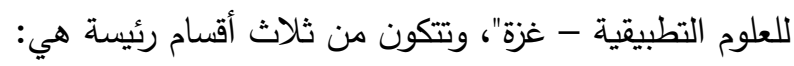

القسم الأول: وهو عبارة عن بيانات شخصية عن المستجيبين تتضمن (المؤهل العلمي، الجنس، سنوات الخبرة).

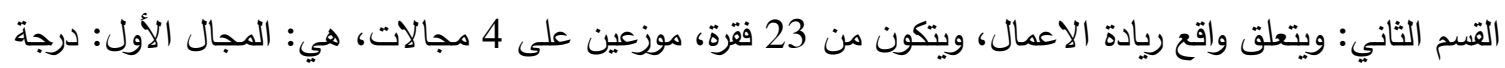

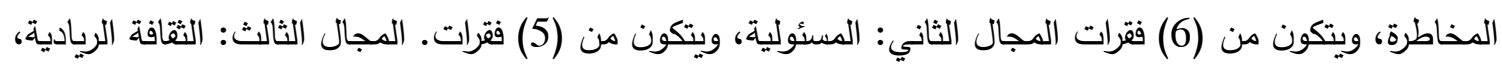

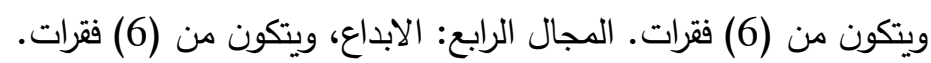

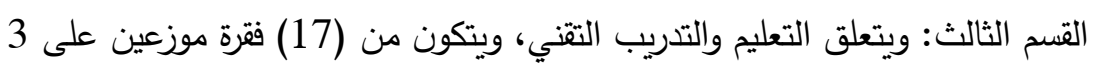

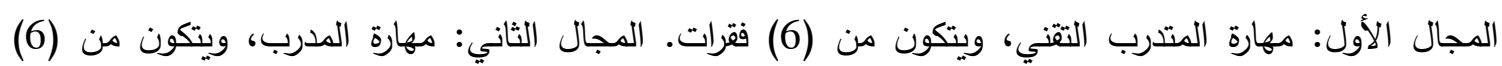

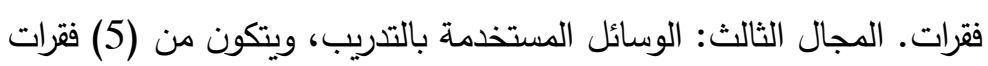


- وقد تم استخدام المقياس من 1-10 لقياس استجابات المبحوثين لفقرات الاستبانة، حيث أنه كلما اقتربت الدرجة من الرقم 10 دلَّ ذلك على الموافقة الثديدة على ما ورد في الفقرة والعكس صحيح. سادساً: خطوات بناء الاستبانة:

قام الباحث بإعداد أداة الدراسة للتعرف على "واقع ريادة الأعمال في كليات التعليم التقني: دراسة تطبيقية

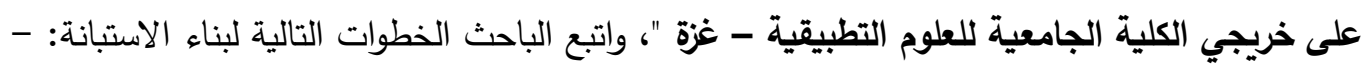
تم مراجعة أسئلة وأهداف ومتغيرات وفرضيات الدراسة، ومراجعة أدبيات الدراسة، والاستفادة من الخبراء من ذوي لوني الاختصاص في تحديد مجالات الاستبانة وتصميم الاستبانة وتحكيمها من جهة المحكمين.

سابعاً: صدق الاستبانة Validity: تم التأكد من صدق الاستبانة بطريقتين: 1. الصدق من وجهة نظر المحكمين "الصدق الظاهري": حيث تم عرض الاستبانة على مجموعة من المحكمين تألفت من (4) من المتخصصين في مجال الدراسة وقد استجاب الباحث لآراء المحكمين. 2. صدق المقياس وثبات الاستبانة: الاتساق الداخلي Internal Validity يقصد بصدق الاتساق الداخلي مدى اتساق كل فقرة من فقرات الاستبانة مع المجال الذي تتنمي إلية هذه الفقرة، وقد قام الباحث بحساب الاتساق الداخلي للاستبانة وذلك من خلال حساب معاملات الارتباط بين كل فقرة من فقرات مجالات الاستبانة والدرجة الكلية للدجال نفسه. 1 ـ واقع ريادة الأعمال في الكليات التقنية يوضح جدول (1) معامل الارتباط بين كل فقرة من فقرات مجال والدرجة الكلية للمجال، والذي يبين أن معاملات الارتباط المبينة دالة عند مستوى معنوية 0.05 م وبذلك يعتبر المجال صادقاً لما وضع لقياسه. جدول (1): معامل الارتباط بين كل فقرة من فقرات مجال والارجة الكلية للمجال

\begin{tabular}{|c|c|c|c|}
\hline الاحتيمة & لبيرسون & 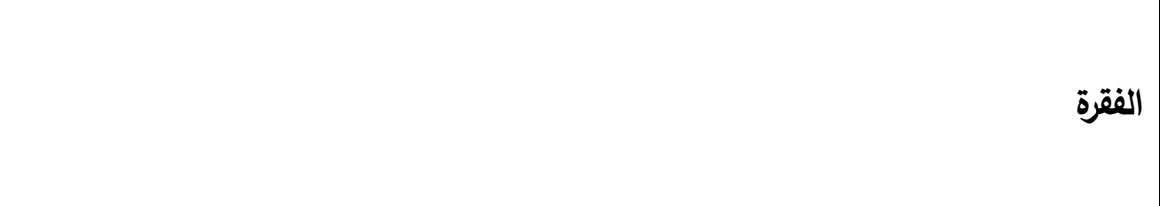 & p \\
\hline \multicolumn{4}{|c|}{ 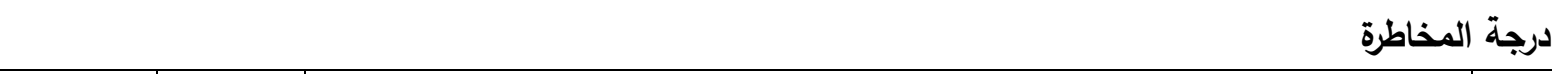 } \\
\hline 0.000 & 0.719 & عززت الكلية لدي قيم الثقة والجرأة في التعامل من خلال المواقف التدريبية. & .1 \\
\hline 0.000 & 0.792 & حرصت الكلية على تقديم كل جديد وبطرق واقعية مع احتساب درجة المخاطرة. & .2 \\
\hline 0.000 & 0.867 & شجعني أسلوب التدريب التقني في الاقبال على انشاء مشاريع جديدة. & .3 \\
\hline 0.000 & 0.785 & تراكم لدي قيم تشجعني على تحمل مسئوليات كبيرة في مجالي عمل المهني. & .4 \\
\hline 0.000 & 0.878 & دعمت الكلية الأفكار الريادية في التدريب وان كانت فيها نوع من المخاطر . & .5 \\
\hline 0.000 & 0.796 & شجعت الكلية مشاريع الطلبة الغير تقليدية أثناء التدريب وان كانت تحمل مخاطر في & .6 \\
\hline \multicolumn{4}{|c|}{ المسئولية } \\
\hline 0.000 & 0.687 & حرصت الكلية بمسؤولية عالية على تقديم أفضل خدمات تعليمية ومهنية. & .1 \\
\hline
\end{tabular}




\begin{tabular}{|c|c|c|c|}
\hline $\begin{array}{c}\text { القيمة } \\
\text { الاحتمالية } \\
\text { (Sig) }\end{array}$ & لبيرسون & 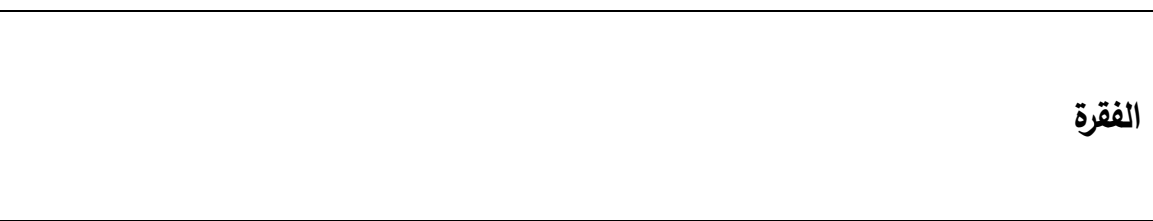 & b \\
\hline 0.000 & 0.849 & عززت الكلية بعض الصفات القيادية لدى الطلبة خلال فترة الدراسة. & .2 \\
\hline 0.001 & 0.574 & شجعت الكلية الطلبة على ثقافة التفكير المستقل واتخاذ القرار . & .3 \\
\hline 0.000 & 0.909 & تلعمت أثناء دراستي في الكلية الحرية بالعمل والقدرة على تحمل المسئوليات لإنجاز & .4 \\
\hline 0.000 & 0.925 & غرست الكلية الكثير من قيم التحدي والمبادرة والاصرار والانجاز خلال فترة الدراسة. & .5 \\
\hline \multicolumn{4}{|c|}{ الثقافة الريادية } \\
\hline 0.000 & 0.889 & حرصت الكلية على تثجيع أفكارنا التطويرية خلال فترة الدراسة. & .1 \\
\hline 0.002 & 0.544 & عملت الكلية على زيادة وعي الطلبة لأهمية المشاريع الجديدة الابداعية. & .2 \\
\hline 0.000 & 0.687 & منحت الكلية حوافز لتتفيذ مشاريع تخرج ذات طابع ريادي لبعض الطلبة. & .3 \\
\hline 0.000 & 0.776 & ساهم محتوى المناهج والوسائل التدريبية على تتمية أفكاري الابداعية. & .4 \\
\hline 0.000 & 0.855 & شجعت الكلية قيم الانجاز والابداع أثناء فترة الدراسة. & .5 \\
\hline 0.000 & 0.738 & حفزت الكلية على مبدأ المبادرة والمجازفة لإنجاز أفكار ومشاريع ريادية. & .6 \\
\hline \multicolumn{4}{|c|}{ 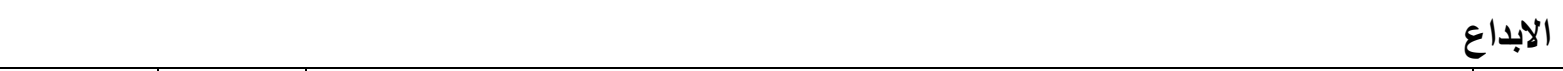 } \\
\hline 0.000 & 0.697 & شجعت الكلية الطلبة على التفكير الابداعي خلال العملية التعليمية. & .1 \\
\hline 0.000 & 0.917 & وفرت الكلية بيئة مناسبة تثجع على التفكير الحر وتقبل كل ما هو جديد. & .2 \\
\hline 0.000 & 0.896 & ساهدت الأدوات والأجهزة الحديثة بالكلية الطلبة على انتاج مشاريع ابداعية. & .3 \\
\hline 0.000 & 0.699 & حرصت الكلية على تمويل مشاريع الطلبة الجديدة ذات المواصفات الابداعية. & .4 \\
\hline 0.000 & 0.870 & أنتجت أققام الكلية العديد من المشاريع الابداعية المنتجة خلال فترة الدراسة. & .5 \\
\hline 0.000 & 0.944 & دعمت الكلية الطلبة على استخدام أساليب جديدة في التطبيقات المهنية خلال فترة & .6 \\
\hline
\end{tabular}

م الارتباط دال إحصائياً عند مستوى دلالة 0.05 .

$$
\text { 2. التعليم والتدريب التقني }
$$

يوضح جدول (2) معامل الارتباط بين كل فقرة من فقرات مجال والدرجة الكلية للمجال، والذي يبين أن معاملات الارتباط المبينة دالة عند مستوى معنوية 0.05 م وبذلك يعتبر المجال صادقاً لما وضع لقياسه. جدول (2): معامل الارتباط بين كل فقرة من فقرات مجال واللارجة الكلية للمجال

\begin{tabular}{|c|c|c|c|}
\hline الاحتمالية & لبيرسون & الفقرة & م \\
\hline \multicolumn{4}{|c|}{ مهارة المتدرب التقني } \\
\hline 0.000 & 0.871 & أستطيع ممارسة المهارات المهنية التي تدربت عليها بكفاءة في واقع العمل. & .1 \\
\hline 0.000 & 0.903 & أكسبني التدريب المهني مهارات تؤهلني للمنافسة على وظائف مهنية متخصصة. & .2 \\
\hline
\end{tabular}




\begin{tabular}{|c|c|c|c|}
\hline القيمة الاحتمالية & لبرسون & الفقرة & م \\
\hline 0.000 & 0.922 & اكتسبت من الكلية مهارات عملية ابداعية ساعدت في تطوير قدراتي المهنية. & .3 \\
\hline 0.000 & 0.791 & ساهدت المهارات التدريبية التي اكتسبتها في الحصول على فرص متتوعة في & .4 \\
\hline 0.000 & 0.893 & ساعدت المهارات التي اكتسبتها من التدريب في تتمية تفكيري الابتكاري. & .5 \\
\hline 0.000 & 0.888 & مناسب. حرص المدربون بالكلية على استخدم أدوات تتييم للتأكد من تطبيق المهارات بشكل & .6 \\
\hline \multicolumn{4}{|c|}{ 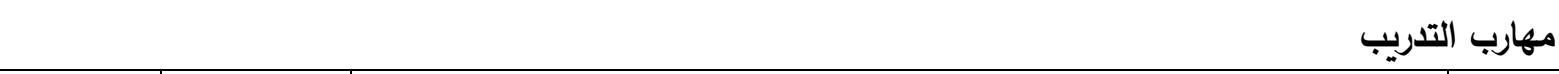 } \\
\hline 0.003 & 0.531 & اتصف معظم المدربين في الكلية بمهارات عالية في التدريب التقني. & .1 \\
\hline 0.000 & 0.944 & استخدم المدربون أحدث الأجهزة أثناء التدريب بأسلوب ابداعي. & .2 \\
\hline 0.000 & 0.965 & حرصت الكلية على تقييم أداء المدربين من خلال نماذج تقيس رأي المتدربين & .3 \\
\hline 0.000 & 0.868 & الكتسبت من الدربين بالكلية مهارات ريادية ساعدتني على المنافسة في سوق & .4 \\
\hline 0.000 & 0.938 & استخدم المدربون تجارب تدريبية حديثة في التدريب المهني. & .5 \\
\hline 0.000 & 0.935 & حرص المدربون باستمرار على استخدام وسائل تقييم للتأكد من اكساب المهارات & .6 \\
\hline \multicolumn{4}{|c|}{ الوسائل المستخدمة بالتدريب } \\
\hline 0.000 & 0.964 & اتصف معظم المدربين في الكلية بمهارات عالية في التتريب التقني. & .1 \\
\hline 0.000 & 0.932 & استخدم المدربون أحدث الأجهزة أثناء التدريب بأسلوب ابداعي. & .2 \\
\hline 0.000 & 0.857 & بالعملية التدريبية. الكلية على تقييم أداء المدربين من خلال نماذج تقيس رأي المتدربين & .3 \\
\hline 0.000 & 0.872 & العتسبت من الددربين بالكلية مهارات ريادية ساعدتني على المنافسة في سوق & .4 \\
\hline 0.000 & 0.938 & استخدم المدربون تجارب تدريبية حديثة في التدريب المهني. & .5 \\
\hline
\end{tabular}

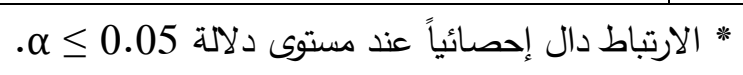

ب - الصدق البنائي Structure Validity يعتبر الصدق البنائي أحد مقاييس صدق الأداة الذي يقيس مدى تحقق الأهداف التي تريد الأداة الوصول

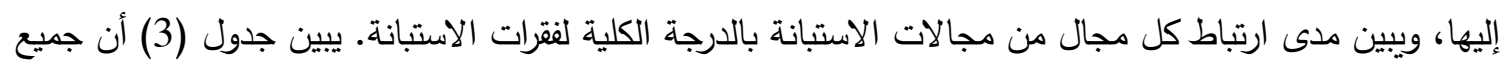

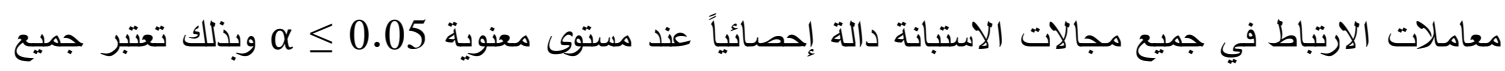

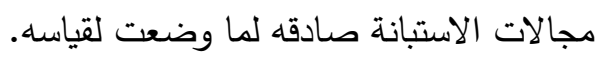


جدول (3): معامل الارتباط بين درجة كل مجال من مجالات الاستبانة والارجة الكلية للاستبانة

\begin{tabular}{|c|c|c|}
\hline الاحتمالية(Sig) & 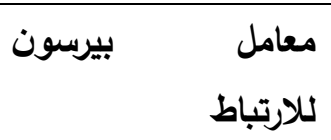 & المجال \\
\hline 0.000 & 0.887 & درجة المخاطرة \\
\hline 0.000 & 0.889 & المسئولية \\
\hline 0.000 & 0.961 & الثقافة الريادية \\
\hline 0.000 & 0.867 & 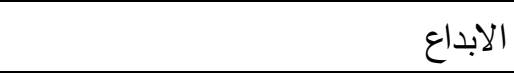 \\
\hline 0.000 & 0.954 & واقع ريادة الأعمال في الكليات التقنية \\
\hline 0.000 & 0.950 & مهارة المتدرب التتني \\
\hline 0.000 & 0.966 & مهارة المدرب \\
\hline 0.000 & 0.944 & الوسائل المستخدمة بالتدريب \\
\hline 0.000 & 0.947 & التعليم والتدربب التقني \\
\hline
\end{tabular}

ثبات الاستبانة Reliability:

وقد تحقق الباحث من ثبات استبانة الدراسة من خلال معامل ألفا كرونباخ Cronbach's Alpha Coefficient، وكانت النتائج كما هي مبينة في جدول (4). جدول (4): معامل ألفا كرونباخ لقياس ثبات الاستبانة

\begin{tabular}{|c|c|c|}
\hline معامل ألفا كرونباخ & عدد الفقرات & 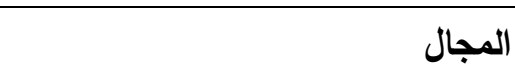 \\
\hline 0.891 & 6 & درجة المخاطرة \\
\hline 0.823 & 5 & المسئولية \\
\hline 0.829 & 6 & الثقافة الريادية \\
\hline 0.913 & 6 & الابداع \\
\hline 0.954 & 23 & واقع ربادة الأعمال في الكليات التقنية \\
\hline 0.933 & 6 & مهارة المتدرب التقني \\
\hline 0.938 & 6 & 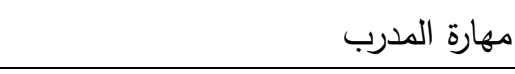 \\
\hline 0.949 & 5 & الوسائل المستخدمة بالتدريب \\
\hline 0.974 & 17 & التعليم والتدريب التقني \\
\hline 0.977 & 40 & جميع فقرات الاستبانة \\
\hline
\end{tabular}

واضح من النتائج الموضحة في جدول (4) أن قيمة معامل ألفا كرونباخ لجميع فقرات الاستبانة (0.977)، وهذا يعنى أن الثبات مرتفع ودال إحصائياً.

ثامناً: الأساليب الإحصائية المستخدمة:

Statistical Package for the Social تم تقريغ وتحليل الاستبانة من خلال برنامج التحليل الإحصائي (SPSS) Sciences 
وقد تم استخدام الأدوات الإحصائية التالية: 1. النسب المئوية والتكرارات (Frequencies \& Percentages): لوصف الإحصائه عينة الدراسة. 2. المتوسط الحسابي والمتوسط الحسابي النسبي والانحراف المعياري. 3. اختبار ألفا كرونباخ (Cronbach's Alpha) لمعرفة ثبات فقرات الاستبانة.

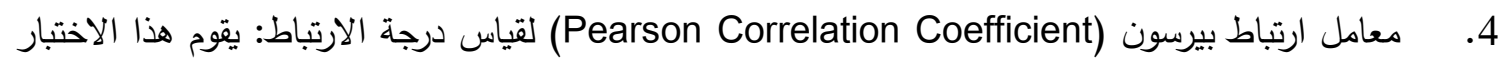
على دراسة العلاقة بين متغيرين. وقد استخدمه الباحث لحساب الاتساق الداخلي والصدق البنائي للاستبانة وكذلك لدراسة العلاقة بين المجالات.

5. نموذج تحليل الانحدار الخطي المتعدد (Multiple Linear Regression- Model). 6. اختبار تحليل التباين الأحادي( One Way Analysis of Variance - ANOVA) لمعرفة ما إذا كان هناك فروقات ذات دلالة إحصائية بين ثلاث مجموعات أو أكثر من البيانات.

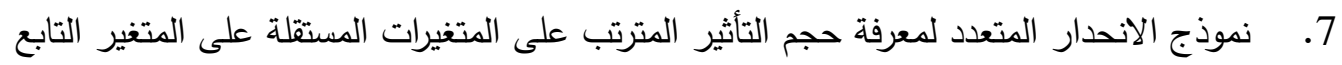

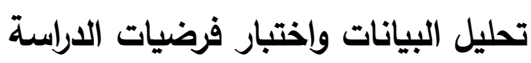
أولاً: الوصف الإحصائي لعينة الدراسة وفق البيات وانئار عرضيات الإسهة الثخصية: فيما يلي عرض لخصائص عينة الدراسة وفق البيانات الثخصية:

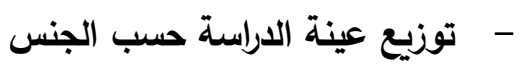

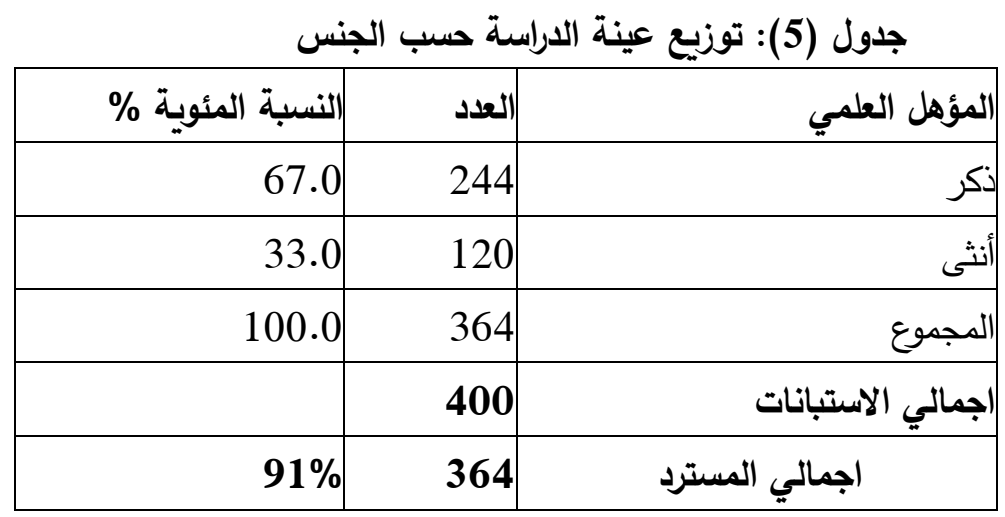

يتضح من جدول (5) أن ما نسبته 67.0\% من عينة الدراسة هم من الذكور ، بينما 33.0\% هم من الاناث

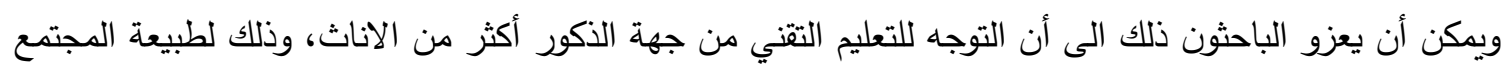
الفلسطيني الذي لا يثجع العمل التقني للإناث.

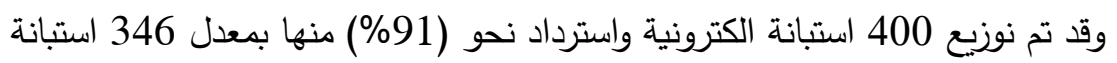
- - توزيع عينة الاراسة حسب المؤهل العلمي جدول (6): توزيع عينة الدراسة حسب المؤهل العلمي

\begin{tabular}{|c|c|c|}
\hline |النسبة المئوية \% & |لعدد & |المؤهل العلمي \\
\hline 3.6 & 13 & أقل من ثانوية عامة \\
\hline 5.8 & 21 & ثانوية عامة \\
\hline 90.6 & 330 & دبلوم متوسط \\
\hline 100.0 & 364 & موع \\
\hline
\end{tabular}


يتضح من جدول (6) أن ما نسبته 3.6\% من عينة الدراسة هم من الذين مؤهلهم أقل من ثانوية عامة، بينما 5.8\% هم من ثانوية عامة، بينما 90.6\% هم من دبلوم متوسط، ويمكن أن يرجع تدني نسب فئة المبحوثين

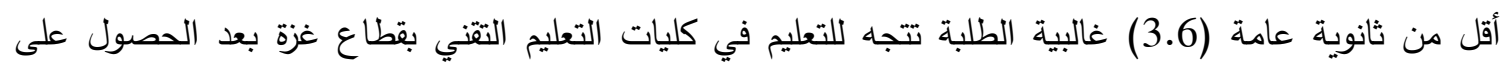
الثانوية العامة.

- - توزيع عينة الاراسة حسب سنوات الخبرة

جدول (7): توزيع عينة الاراسة حسب سنوات الخبرة الخبرة

\begin{tabular}{|c|c|c|}
\hline | النسبة المئوية \% & | العدد & سنوات الخبرة \\
\hline 77.2 & 281 & أقل من 5 \\
\hline 6.0 & 22 & 5- 10 سنوات \\
\hline 11.3 & 41 & 10-15 سنة \\
\hline 5.5 & 20 & 15 فُأكثر \\
\hline 100.0 & 364 & المجموع \\
\hline
\end{tabular}

يتضح من جدول (7) أن ما نسبته 77.2\% من عينة الدراسة هم من الذين سنوات خبرتهم أقل من 5

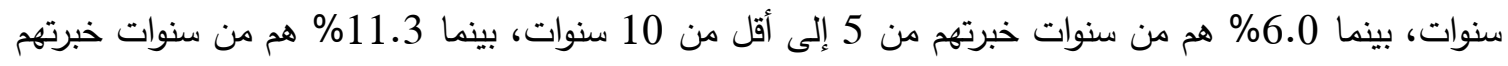
من 10 إلى أقل من 15 سنة، بينما 5.5\% هم من الذين سنوات خبرتهم 15 سنة فأكثر، مدكن أن يرجع الباحثون

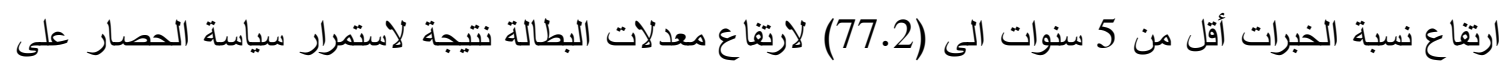
قطاع غزة. ثالثاً: تحليل فقرات الاستبانة: 1. تحليل فقرات واقع ريادة الأعمال في الكليات التقنية: تم استخدام المتوسط الحسابي والانحراف المعياري والوزن النسبي والترتيب لمعرفة درجة الموافقة. النتائج موضحة في جدول (). (م)

جلول (8): المتوسط الحسابي والانحراف المعياري والوزن النسبي والترتيب لكل الفقرات

\begin{tabular}{|c|c|c|c|c|c|c|}
\hline المورجة & الترتيب & 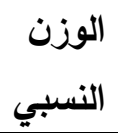 & 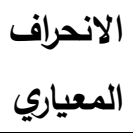 & الحستوسط & 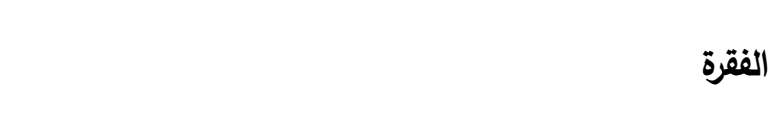 & s \\
\hline \multicolumn{7}{|c|}{ درجة المخاطرة } \\
\hline كبيرة & 2 & 76.40 & 2.028 & 7.64 & عززت الكلية لدي قيم الثقة والجرأة في التعامل من خلال & .1 \\
\hline كبيرة & 3 & 71.80 & 2.379 & 7.18 & حرصت الكلية على تقديم كل جديد وبطرق واقعية مع & .2 \\
\hline متوسطة & 6 & 61.80 & 2.850 & 6.18 & شجاريع جديدة. أسلوب التدريب التقني في الاقبال على انثاء & .3 \\
\hline كبيرة & 1 & 78.60 & 2.289 & 7.86 & تراكم لدي قيم تثجعني على تحمل مسئوليات كبيرة في & .4 \\
\hline
\end{tabular}




\begin{tabular}{|c|c|c|c|c|c|c|}
\hline & & & & & مجالي عمل المهني. & \\
\hline كبيرة & 4 & 67.70 & 2.554 & 6.77 & |نوع من المخاطر الكلية الأفكار الريادية في التدريب وان كانت فيها & .5 \\
\hline كبيرة & 5 & 65.80 & 2.662 & 6.58 & 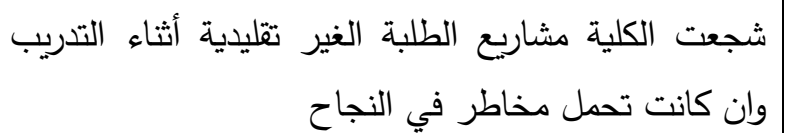 & .6 \\
\hline كبيرة كبير & 4 & 70.30 & 2.023 & 7.03 & \multirow{2}{*}{\multicolumn{2}{|c|}{ المسئولية الكلية لجميع فقرات مجال درجة المخاطرة }} \\
\hline & & & & & & \\
\hline كبيرة & 5 & 76.90 & 2.406 & 7.69 & | تعليمية ومهنية. & .1 \\
\hline كبيرة & 1 & 83.10 & 2.050 & 8.31 & فترة الدراسة. & .2 \\
\hline كبيرة & 4 & 80.30 & 1.938 & 8.03 & القرار. شجعت الكلية الطلبة على ثقافة التفكير المستقل واتخاذ & .3 \\
\hline كبيرة & 3 & 80.60 & 2.156 & 8.06 & 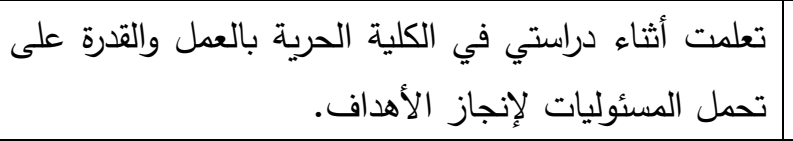 & .4 \\
\hline كبيرة & 2 & 81.80 & 1.880 & 8.18 & غرالانجاز خلال فترة الدراسة. الكثير من قيم التحدي والمبادرة والاصرار & .5 \\
\hline كبيرة & 1 & 80.50 & 1.795 & 8.05 & \multicolumn{2}{|l|}{ الدرجة الكلية لجميع فقرات مجال المسئولية } \\
\hline \multicolumn{7}{|c|}{ الثقافة الريادية } \\
\hline كبيرة & 2 & 77.00 & 2.412 & 7.70 & | حرصت الكلية على تشجيع أفكارنا التطويرية خلال فترة & .1 \\
\hline كبيرة & 3 & 76.90 & 2.418 & 7.69 & عملت الكلية على زيادة وعي الطلبة لأهمية المشاريع & .2 \\
\hline كبيرة & 5 & 72.80 & 2.581 & 7.28 & |لبعض الطلبة. & .3 \\
\hline كبيرة & 1 & 77.20 & 2.244 & 7.72 & |لابداعية. & .4 \\
\hline 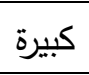 & 4 & 75.30 & 1.983 & 7.53 & شجعت الكلية قيم الانجاز والابداع أثناء فترة الدراسة. & .5 \\
\hline كبيرة & 6 & 71.10 & 2.472 & 7.11 & | ومشاريع ريادية. & .6 \\
\hline كبيرة & 3 & 70.50 & 1.917 & 7.50 & \multicolumn{2}{|l|}{ الدرجة الكلية لجميع فقرات مجال الثقافة الريادية } \\
\hline \multicolumn{7}{|c|}{ 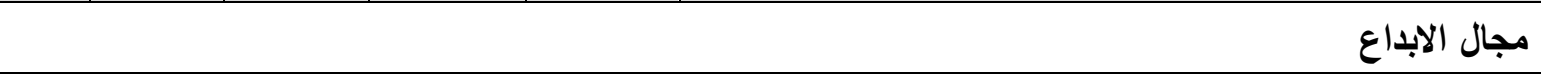 } \\
\hline كبيرة & 1 & 77.10 & 2.182 & 7.71 & شجعت الكلية الطلبة على التفكير الابداعي خلال العملية & .1 \\
\hline
\end{tabular}




\begin{tabular}{|c|c|c|c|c|c|c|}
\hline كبيرة & 3 & 71.60 & 2.579 & 7.16 & كل ما هو جديد. الكلية بيئة مناسبة تشجع على التفكير الحر وتقبل & .2 \\
\hline كبيرة & 4 & 68.70 & 2.555 & 6.87 & مشاهدت الأدوات والأجهزة الحديثة بالكلية الطلبة على انتاج & .3 \\
\hline كبيرة & 5 & 68.00 & 2.504 & 6.80 & حرصت الكلية على تمويل مشاريع الطلبة الجديدة ذات & .4 \\
\hline كبيرة & 6 & 65.30 & 2.498 & 6.53 & خلا فتجت أقسام الكلية العديد من المشاريع الابداعية المنتجة & .5 \\
\hline كبيرة & 2 & 75.00 & 2.030 & 7.50 & التطبيقات المهنية خلال فترة الدراسة. الطلبة على أستام اليب جديدة في & .6 \\
\hline كبيرة & 2 & 71.00 & 2.040 & 7.10 & \multicolumn{2}{|c|}{ الارجة الكلية لجميع فقرات مجال الابداع } \\
\hline كبيرة & & 73.90 & 1.799 & 7.39 & \multicolumn{2}{|l|}{ التقرجة الكلية لجميع فقرات واقع رياد الأعمال في الكليات } \\
\hline
\end{tabular}

تبين أن ترتيب أبعاد واقع ريادة الأعمال جاءت على النحو الاتي: - قد حصل مجال "المسئولية" على المرتبة الأولى بوزن نسبي قدره

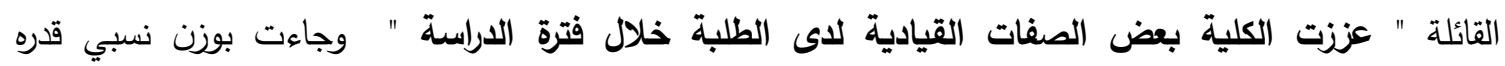

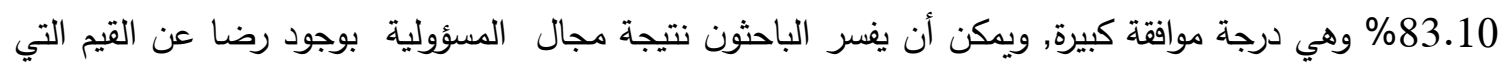
تزرع روح المسئولية من الكلية, ويمكن الاستتاد عليها وتعزيزها, وهذه النتيجة تتفق مع دراسة (Duman, 2015) أن من أهم صفات الريادي الاستقلال والتعلم والطموح العالي للنجاح, ودراسة (Alcaraz,et al., 2019) , التئي

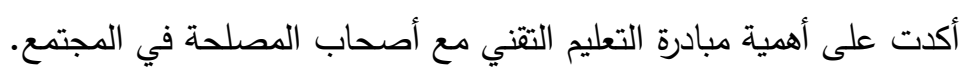
- وفي المرتبة الثانية مجال "الابداع" جاء بوزن نسبي قدره 71.00\% وقد جاءت أعلى أعلى فقرة من مكوناته القائلة "

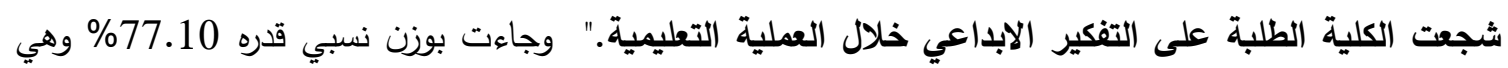

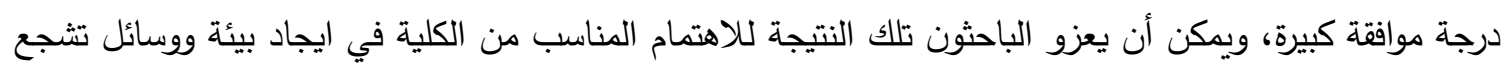

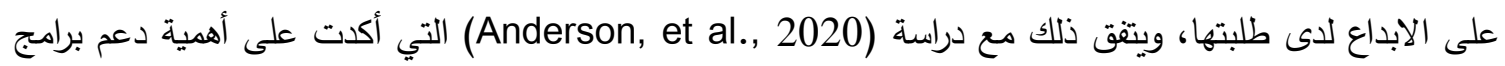
التدريب التقني الريادي, ودراسة (Alcaraz,et al., 2019) التي شجعت على أهمية روح المبادرة ما بين التعليم التقني والقطاعين الخاص والعام. - وفي المرتبة الثالثة مجال "الثقافة الريادية" جاء بوزن نسبي قدره 70.50\% وقد جاءت أعلى فقرة من مكوناته

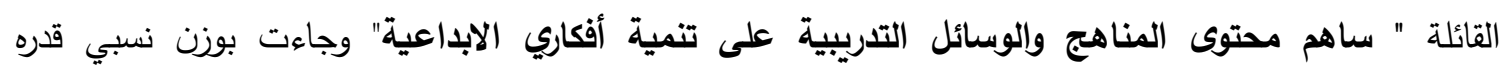

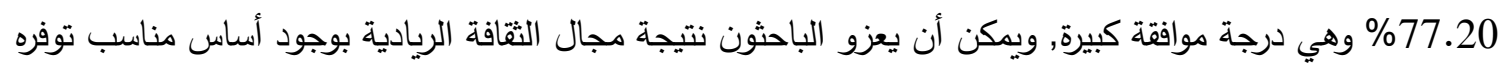

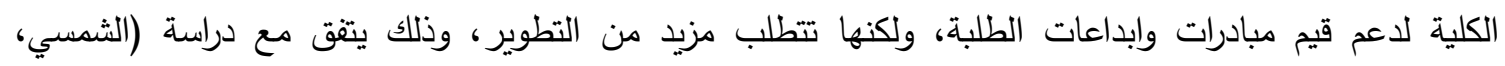

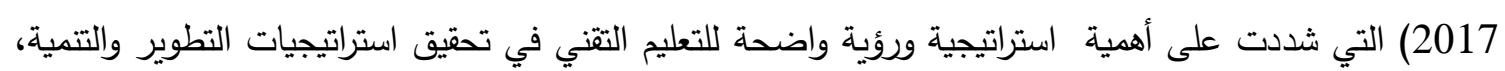
ودراسة (Duman, 2015) التي وضحت أهمية قيم الريادة والرغبة في الاختراع والاستقلال والتعلم والطموح العالي للنجاح في التعليم التقني. 
- وفي المرتبة الرابعة مجال "درجة المخاطرة" جاء بوزن نسبي قدره 70.30\% وقد جاءت أعلى فقرة من مكوناته

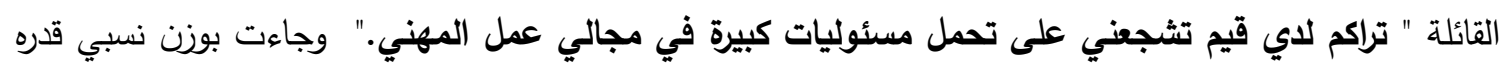

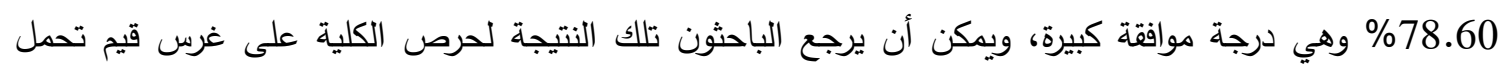

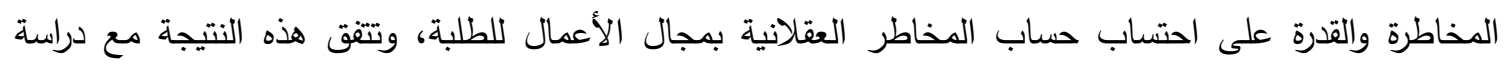
(Badariah, 2016) ودراسة (Duman, 2015) التي أكدت على أهمية صفات الريادي في الطموح والاستقلالية والرغبة في الاختراع في المجال التقني الريادي. وأخيراً يمكن القول بأن الوزن النسبي لواقع ريادة الأعمال في الكليات التقنية ككل جاء بوزن نسبي قدره 73.90\%

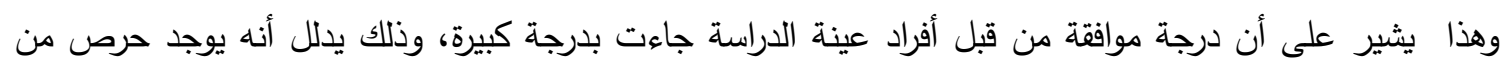

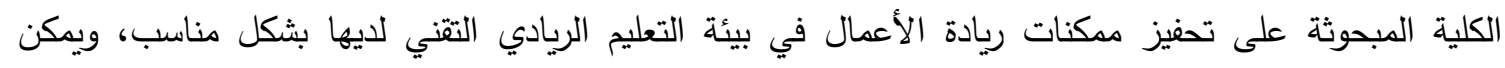
الاستناد عليه في تطوير قدراتها الريادية، وذلك يتقق مع دراسة كل (Anderson, et al., 2020), ودراسة

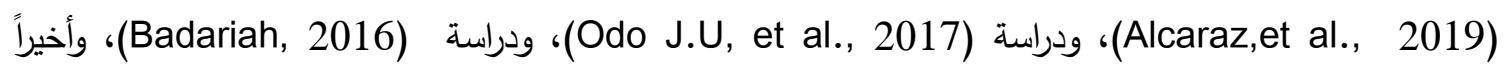
دراسة (Duman, 2015) والتي أكدت جميعها على أهمية الريادة في مجال التعليم التقني. 2. تحليل فقرات التعليم والتدريب التقني:

تم استخدام المتوسط الحسابي والانحراف المعياري والوزن النسبي والترتيب لمعرفة درجة الموافقة. النتائج موضحة في جدول (9).

جدول (9): المتوسط الحسابي والانحراف المعياري والوزن النسبي والترتيب لكل الفقرات

\begin{tabular}{|c|c|c|c|c|c|c|}
\hline الموجة & الترتيب & 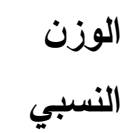 & 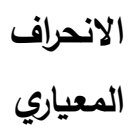 & المتوسط & 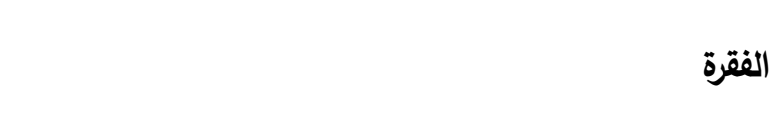 & م \\
\hline \multicolumn{7}{|c|}{ مهارة المتدرب التقني } \\
\hline كبيرة & 3 & 75.50 & 2.421 & 7.55 & في واقتيع العمل. ممارسة المهارات المهنية التي تدربت عليها بكفاءة & .1 \\
\hline كبيرة & 4 & 71.70 & 2.198 & 7.17 & وظكسئفي التدريب المهنية مهارات تؤهلني للمنافسة على & .2 \\
\hline كبيرة & 1 & 76.30 & 2.024 & 7.63 & تطتوير قدراتي المهنية. الكلية مهارات عملية ابداعية ساعدت في & .3 \\
\hline كبيرة & 5 & 69.60 & 2.633 & 6.96 & 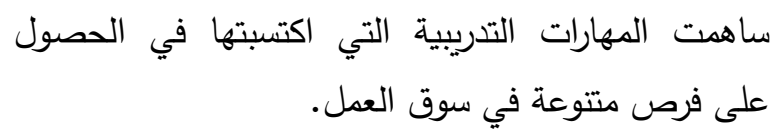 & .4 \\
\hline كبيرة & 2 & 75.60 & 2.271 & 7.56 & تفكيري الابتكاري. المهارات التي اكتسبتها من التدريب في تتمية & .5 \\
\hline كبيرة & 6 & 68.30 & 2.480 & 6.83 & تطبيق المهارات المدربون بالكلية على استخدم أدوات تقييم للتأكد من & .6 \\
\hline كبيرة & 2 & 72.80 & 2.109 & 7.28 & لة الكلية لجميع فقرات مجال مهارة المتدرب التقني & \\
\hline
\end{tabular}




\begin{tabular}{|c|c|c|c|c|c|c|}
\hline كبيرة & 1 & 79.50 & 1.819 & 7.95 & التدريب التقني. معظم المدربين في الكلية بمهارات عالية في & .1 \\
\hline كبيرة & 5 & 71.80 & 2.374 & 7.18 & |رابتخدم المدربون أحدث الأجهزة أثناء التدريب بأسلوب & .2 \\
\hline كبيرة & 6 & 70.50 & 2.237 & 7.05 & تقيس رأي المتدربين بالعملية على تقييم أداء التدربينية من خلال نماذج & .3 \\
\hline كبيرة & 2 & 75.50 & 2.284 & 7.55 & المنافسة في سوق العمل. & .4 \\
\hline كبيرة & 2 & 72.50 & 2.354 & 7.25 & لالانتخدم المدربون تجارب تدريبية حديثة في التدريب & .5 \\
\hline كبيرة & 3 & 73.50 & 2.309 & 7.35 & من اكساب المهارات المحددة. & .6 \\
\hline كبيرة & 1 & 73.90 & 1.984 & 7.39 & \multicolumn{2}{|c|}{ الارجة الكلية لجميع فقرات مجال مهارة المدرب } \\
\hline \multicolumn{7}{|c|}{ الوسائل المستخدمة بالتدريب } \\
\hline كبيرة & 3 & 69.50 & 2.560 & 6.95 & حرصت الكلية على توفير أحدث الأجهزة التي تساعد على الأداعـ. & .1 \\
\hline كبيرة & 4 & 69.40 & 2.476 & 6.94 & بالحداثة. & .2 \\
\hline كبيرة & 2 & 71.90 & 2.251 & 7.19 & 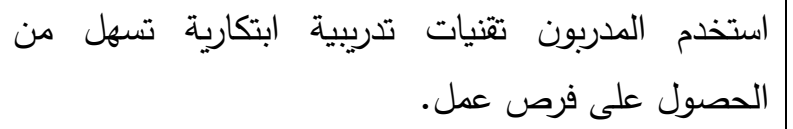 & 3 \\
\hline متوسطة & 5 & 66.10 & 2.741 & 6.61 & اهتمت الكلية باستمرار على تجديد كافة الأجهزة التدريبية. & .4 \\
\hline كبيرة & 1 & 73.30 & 2.863 & 7.33 & تكنولوجيا حديثة مناسبة لسوق العمل. المستخدة في التدريب أنها ات & .5 \\
\hline كبيرة & 3 & 70.00 & 2.349 & 7.00 & جة الكلية لجميع فقرات مجال الوسائل المستخدمة بالتدريب & \\
\hline كبيرة & & 72.40 & 1.970 & 7.24 & جة الكلية لجميع فقرات التعليم والتدربب التقني & \\
\hline
\end{tabular}

تبين أن ترتيب أبعاد واقع ريادة الأعمال جاءت على النحو الاتي: - قد حصل مجال "مهارة المدرب" على المرتبة الأولى بوزن نسبي قدره مكوناته القائلة "اتصف معظم المدربين في الكلية بمهارات عالية في التدربب التقني" وجاءت بوزن نسبي قدره

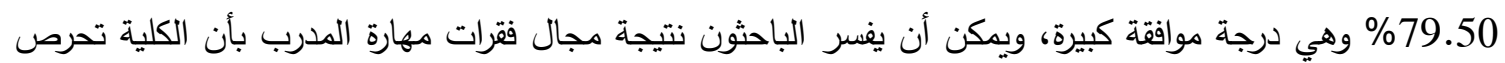

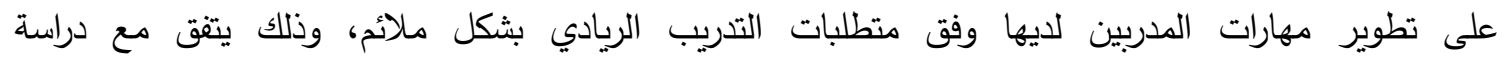
(Alcaraz,et al., 2019)

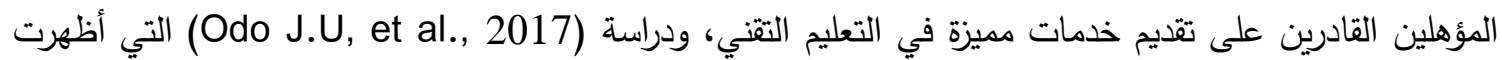
أن ضعف مهارات التدريب في مؤسسات التعليم التقني من أهم أسباب تأخر عجلة التنمية. 
- وفي المرتبة الثانية مجال "مهارة المتدرب التقني" جاء بوزن نسبي قدره 72.80\% وقد جاءت أعلى فقرة من

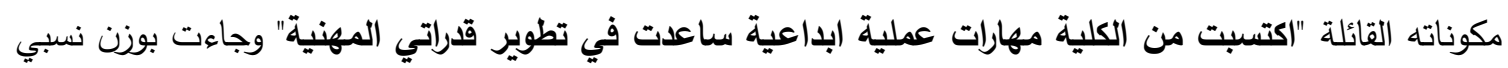
قدره 76.30\% وهي درجة موافقة كبيرة، ويمكن أن يعزو الباحثون نتيجة مجال مهارة المتدرب التقني بأن الكلية محل البحث استطاعت نقل مهارات ملائمة في مجال التدريب التقني للخريجين، ممكن أن تساعدهم في الحصون مونه على فرص عمل، وذلك يتفق مع دراسة (Alcaraz,et al., 2019) التي أكدت على أهمية الفنيين المؤهلين تقنياً

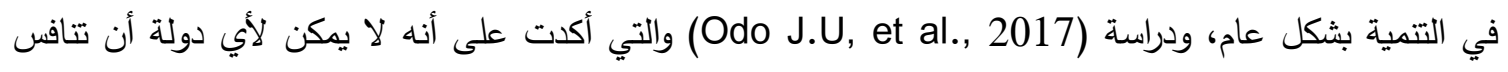
بفعالية في السوق العالمية الا من خلال القوى العاملة ذات المستوى التعليم المهني العالي.

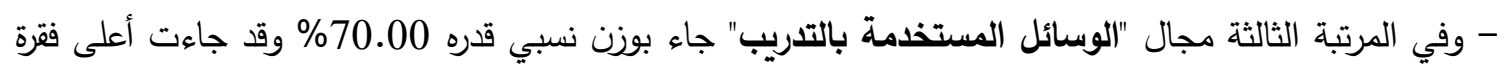

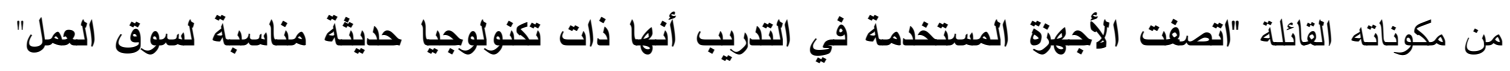
وجاءت بوزن نسبي قدره 73.30\% وهي درجة موافقة كبيرة, ويمكن أن يرجع الباحثان نتيجة مجال الوسائل

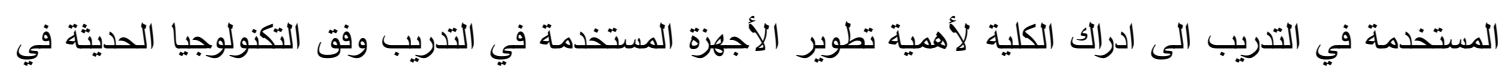

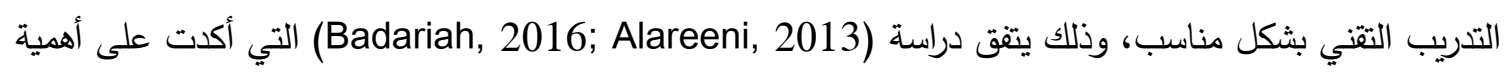
البرامج المعدة جيداً في التعليم التقني، ودراسة (Odo J.U, et al., 2017) التي ذكرت أنه لا يمكن أن تتطور بلد

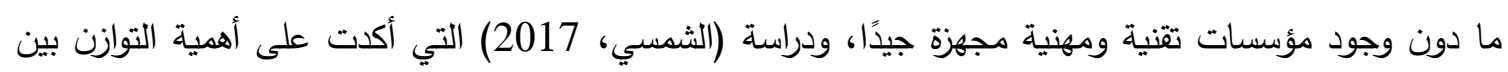
مدخلات ومخرجات التعليم والتتريب التقني والمهني ومتطلبات التنمية.

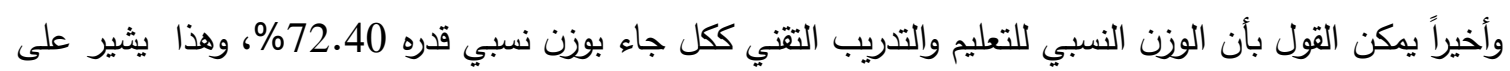
أن درجة موافقة من قبل أفراد عينة الدراسة جاءت بدرجة كبيرة، ويمكن أن يفسر الباحثان نتيجة محور التعليم والتدريب التقني الى أن الكلية محل الدراسة حرصت وبشكل مناسب على توفير بيئة تدريب فاعلة من حيث نوعية

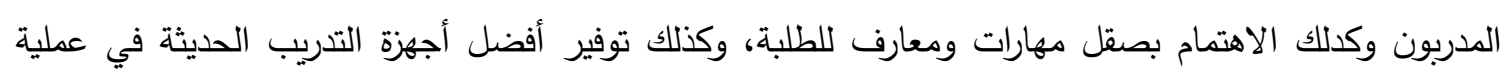

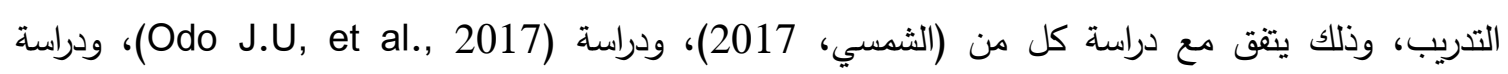

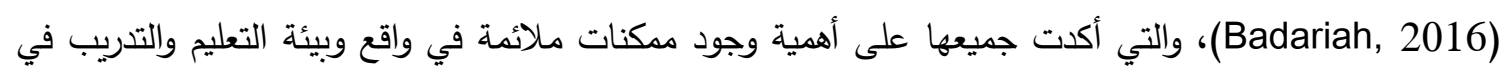

$$
\text { الكليات والمؤسسات التي تعمل بمجال التدريب التقني. }
$$

الفرض الرئيسي الأول: توجد علاقة ذات دلالة احصائية بين ريادة الأعمال وأبعادها (درجة المخاطرة، الثقافة

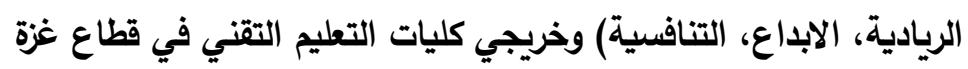

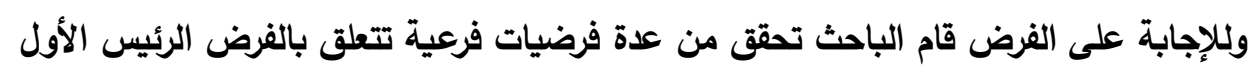
الفرض الفرعي الأول: لا توجد علاقة ذات دلالة احصائية بين درجة المخاطرة وخريجي كليات التعليم التقني في فرضي قطاع غزة للإجابة على هذه الفرضية تم استخدام " معامل بيرسون " لمعرفة درجة وقوة العلاقة بين متغيرين فكانت النتائج كما الجدول (10).

\begin{tabular}{|c|c|c|c|c|}
\hline \multicolumn{4}{|c|}{ خربجي كليات التعليم التقني } & \multirow[b]{2}{*}{ ل درجة المخاطرة } \\
\hline الدلالة الاحصائية & الاحتمالية & $\begin{array}{c}\text { القيمة } \\
\text { (Sig) }\end{array}$ & معامل الارتباط & \\
\hline
\end{tabular}

جدول (10) نتائج معامل الارتباط بيرسون 


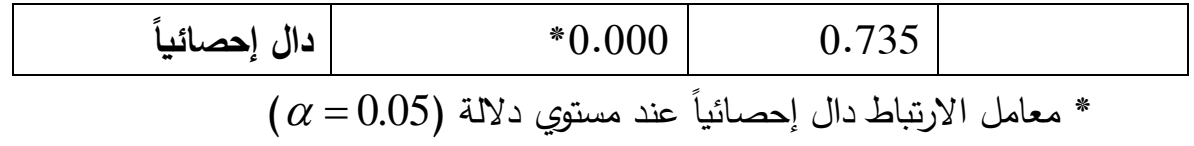

ويتبين من النتائج الموضحة في جدول (10) أن قيمة معامل الارتباط تساوي (0.753) والقيمة الاحتمالية (sig)

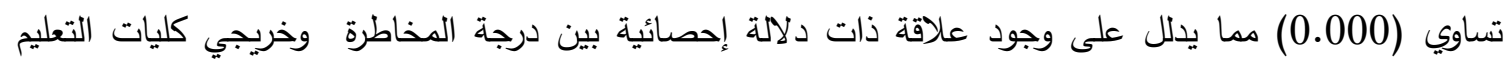

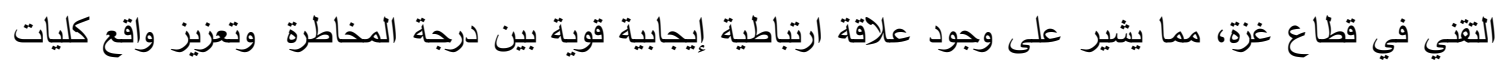
التعليم والتدريب التقني، وتعكس هذه النتيجة دور تحمل المخاطرة العقلانية في تعزيز مخرجات التعليم والتدريب

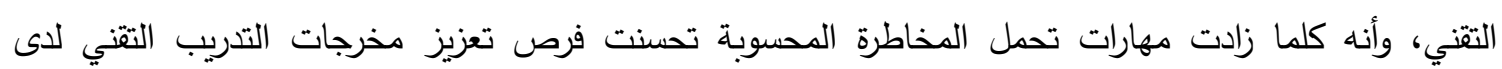
الخريجين، وأن الكلية المبحوثة لديها حرصاً على تحسين واقع وبيئة التدريب التقني. الفرض الفرعي الثاني: لا توجد علاقة ذات دلالة احصائية بين المسئولية وخريجي كليات التعليم التقني في قطاع ولئية للإجابة على هذه الفرضية تم استخدام "معامل بيرسون" لمعرفة درجة وقوة العلاقة بين متغيرين فكانت النتائج كما الجدول (11).

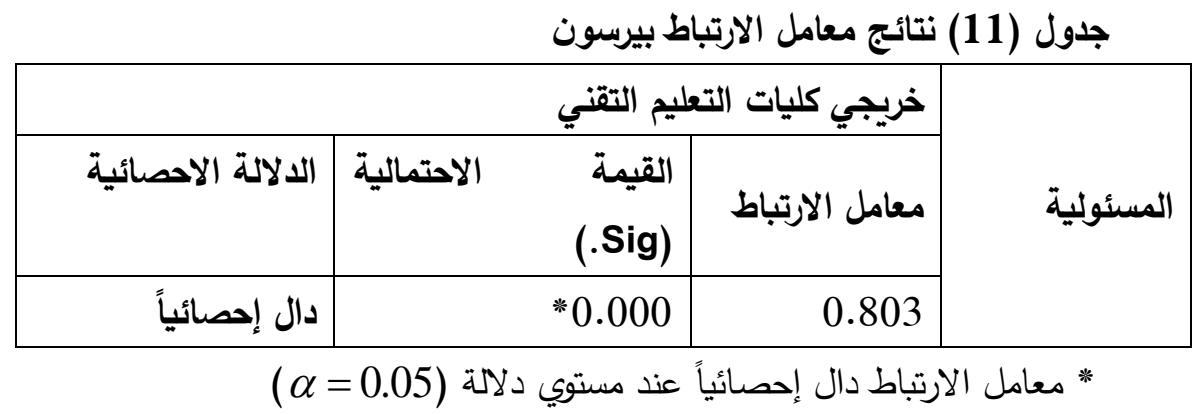

ويتبين من النتائج الموضحة في جدول (11) أن قيمة معامل الارتباط تساوي (0.803) والقيمة الاحتمالية (sig) تساوي (0.000) مما يدلل على وجود علاقة ذات دلالة إحصائية بين درجة المسئولية وخريجي كليات التعليم التقني في قطاع غزة، مما يدلل على وجود علاقة ارتباطية إيجابية قوية بين درجة تحمل المسئولية وتعزيز واقع كليات

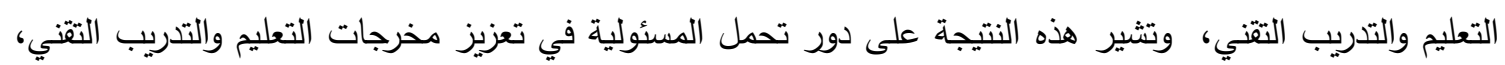
وأنه كلما زادت مهارات تحمل المسئولية زادت فرص تعزيز مخرجات التدريب التقني لدى الخريجين، وأن الكلية المبحوثة لديها حرصاً على تحسين واقع وبيئة التدربب التقني. الفرض الفرعي الثالث: لا توجد علاقة ذات دلالة احصائية بين الثقافة الريادية وخريجي كليات التعليم التقني في قطاع غزة للإجابة على هذه الفرضية تم استخدام "معامل بيرسون" لمعرفة درجة وقوة العلاقة بين متغيرين فكانت النتائج كما الجدول (12).

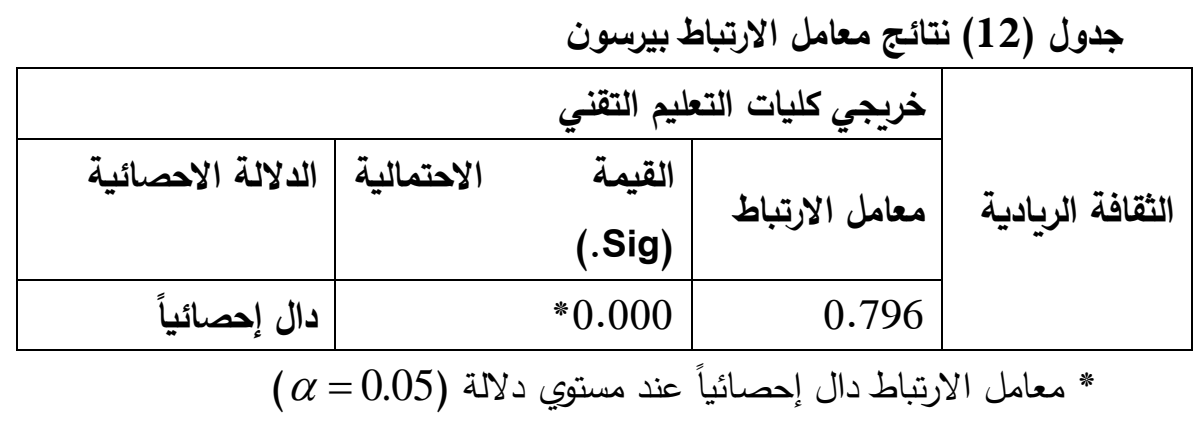


ويتبين من النتائج الموضحة في جدول (12) أن قيمة معامل الارتباط تساوي (0.796) والقيمة الاحتمالية (sig) تساوي (0.000) مما يدلل على وجود علاقة ذات دلالة إحصائية بين الثقافة الريادية وخريجي كليات التعليم التقني في قطاع غزة، مما يوضح على وجود علاقة ارتباطية إيجابية قوية بين توافر الثقافة الريادية وتعزيز واقع كليات التعليم والتدريب التقني، وتدلل هذه النتيجة على دور الثقافة الريادية في تعزيز مخرجات التعليم والتدريب التقني، ولتيه وأنه كلما زاد نشر قيم الثقافة الريادية زادت فرص تعزيز مخرجات التدريب التقني لاى الخريجين، وأن الكلية المبحوثة لديها حرصاً على تحسين واقع وبيئة التدريب التقني. الفرض الفرعي الرابع: لا توجد علاقة ذات دلالة احصائية بين الابداع وخريجي كليات التعليم التقني في قطاع غزة للإجابة على هذه الفرضية تم استخدام "معامل بيرسون" لمعرفة درجة وقوة العلاقة بين متغيرين فكانت النتائج كما الجدول (13).

\begin{tabular}{|c|c|c|c|}
\hline & \multicolumn{3}{|c|}{ جدول (13) نتائج معامل الارتباط بيرسون } \\
\hline & \multicolumn{2}{|c|}{ خريجي كليات التعليم التقني } & \multirow{3}{*}{ الابداع } \\
\hline الالالة الاحصائية & $\begin{array}{c}\text { (القيمة } \\
\text { (Sig) }\end{array}$ & 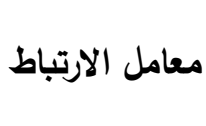 & \\
\hline دال إحصائياً & $* 0.000$ & 0.875 & \\
\hline
\end{tabular}

ويتبين من النتائج الموضحة في جدول (13) أن قيمة معامل الارتباط تساوي (0.875) والقيمة الاحتمالية (sig) تساوي (0.000) مما يدلل على وجود علاقة ذات دلالة إحصائية بين الابداع وخريجي كليات التعليم التقني في التئي قطاع غزة، مما يشير على وجود علاقة ارتباطية إيجابية قوية بين مهارات الابداع وتعزيز واقع كليات التعليم والتدريب التقني، وتدلل هذه النتيجة على دور الابداع في تعزيز مخرجات التعليم والتدريب التقني، وأنه كلما زاد الاهتمام في احتضان المبدعين من الطلبة ارتفعت فرص تعزيز مخرجات التدريب التقني لدى الخريجين، وأن الكلية المبحوثة لديها حرصاً على تحسين واقع وبيئة التدريب التقني. الفرض الرئيسي الثاني: يوجد أثر ذات دلالة احصائية لريادة الأعمال وأبعادها (درجة المخاطرة، الثقافة الريادية،

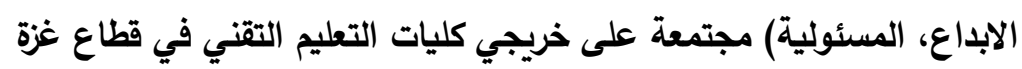

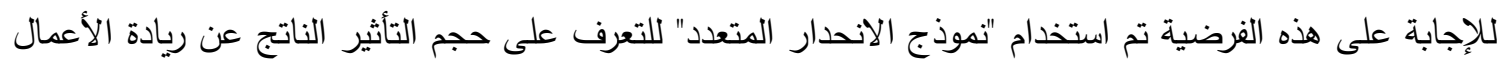

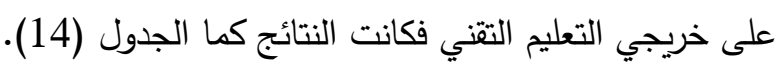
جدول (14) نتائج نموذج الانحدار

\begin{tabular}{|c|c|c|c|c|c|c|}
\hline & المؤشرات الإحصائية & الاحتيمة & $\begin{array}{r}\text { قيمة } \\
\text { (الاختبار } \\
\text { (T) }\end{array}$ & $\begin{array}{r}\text { الخطأ } \\
\text { Std error } \\
\text { المعياري } \\
\end{array}$ & مقدرات & معالم النموذج \\
\hline 903.0 & R معامل الارتباط & 0.513 & 0.654 & 0.205 & 0.134 & المقدار الثابت \\
\hline 0.816 & معامل التحديد $R^{2}$ & 0.000 & 3.920 & 0.045 & 0.176 & درجة المخاطرة \\
\hline 398.082 & F $F$ & 0.000 & 6.023 & 0.053 & 0.318 & المسئولية \\
\hline & & 0.018 & -2.386 & 0.065 & 0.156 & الثقافة الريادية \\
\hline
\end{tabular}




\begin{tabular}{|l|l|l|l|l|l|l|}
\hline & & 0.0000 & 15.966 & 0.039 & 0.630 & الابداع \\
\hline
\end{tabular}
* النموذج المقدر دال إحصائياً عند مستوي دلالة (1/20.05)

ويتبين من النتائج الموضحة في جدول (14) أن القيمة الاحتمالية (sig) لكل متغيرات من المتغيرات الدكونة بأبعاد واقع ريادة الأعمال أقل من مستوى الدلالة 0.05 مما يثير على المتغيرات تؤثر على المتغير التابع خريجي كليات

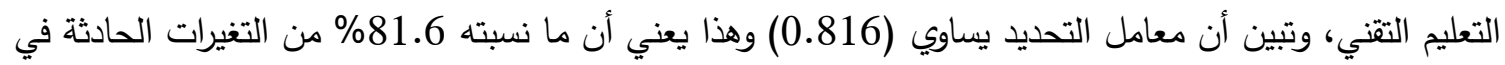

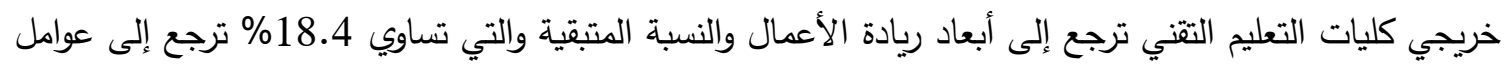

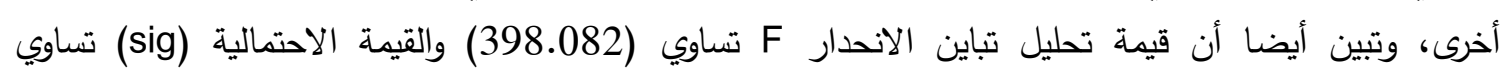
(0.000) وهذا يدلل على وجود أثر ذات دلالة احصائية لريادة الأعمال وأبعادها (درجة المخاطرة، الثقافة الريادية، الابداع، المسئولية) مجتمعة على خريجي كليات التعليم التقني في قطاع غزة وبالتالي يعتبر النموذج المقدر جيد دادئ

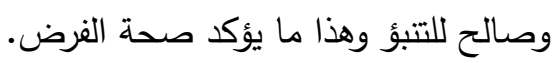
الفرض الرئيسي الثالث: لا توجد فروق معنوية بين آراء المبحوثين حول ريادة الأعمال، وخريجي كليات التعليم

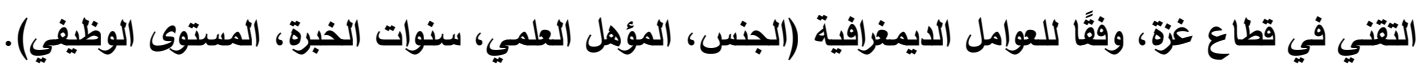
ويشتق من الفرض الثالث الفرضيات الفرعية التالية: 1. لا توجد فروق معنوية بين آراء المبحوثين حول ريادة الأعمال، وخريجي كليات التعليم التقني في قطاع غزة تعزى لمتغير الجنس

\begin{tabular}{|c|c|c|c|c|c|c|}
\hline \multirow{2}{*}{ 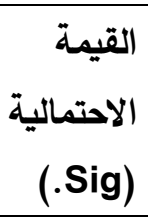 } & \multirow{2}{*}{ قاختة } & \multicolumn{2}{|r|}{ أنثى } & \multicolumn{2}{|r|}{ ذكر } & \multirow[b]{2}{*}{ المجال ل } \\
\hline & & الانحراف & الحسابي & الانحراف & الحستوسط & \\
\hline 0.186 & 1.324 & 1.798 & 7.57 & 1.797 & 7.31 & ريادة الأعمال \\
\hline 0.063 & 1.863 & 1.783 & 7.51 & 2.046 & 7.10 & خريجي $\quad$ كليات \\
\hline 0.107 & 1.618 & 1.734 & 7.55 & 1.841 & 7.22 & جميع المجالات معا \\
\hline
\end{tabular}

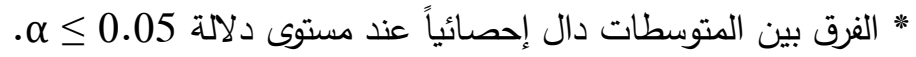

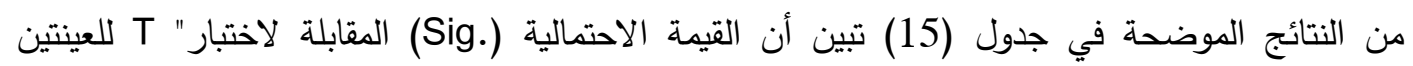

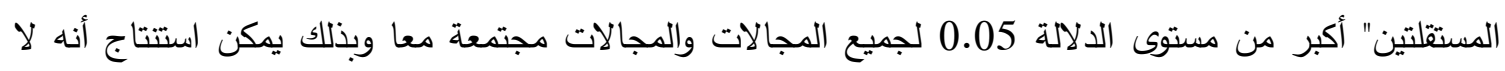

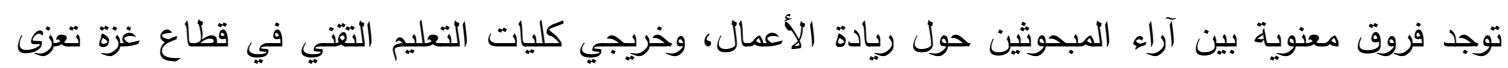
لمتغير الجنس. 2. لا توجد فروق معنوية بين آراء المبحوثين حول ريادة الأعمال، وخريجي كليات التعليم التقني في قطاع غزة تعزى لمتغير المؤهل العلمي 
جدول (16): نتائج اختبار" التباين الأحادي " - المؤهل العلمي

\begin{tabular}{|c|c|c|c|c|c|c|}
\hline \multirow{2}{*}{$\begin{array}{r}\text { القيمة } \\
\text { الاحتمالية } \\
\text { (Sig) }\end{array}$} & \multirow[b]{2}{*}{ قاخمة } & \multicolumn{4}{|c|}{ المتوسطات } & \multirow[b]{2}{*}{ المجال } \\
\hline & & متوسط & عامة & الثانوية & أقل من من & \\
\hline 0.002 & 6.524 & 7.49 & 6.86 & & 5.83 & ريادة الأعمال \\
\hline 0.010 & 4.685 & 7.33 & 6.52 & & 5.94 & خريجي كليات التعليم \\
\hline 0.003 & 6.008 & 7.42 & 6.72 & & 5.88 & جميع المجالات معا \\
\hline
\end{tabular}

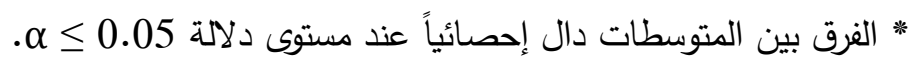
من النتائج الموضحة في جدول (16) تبين أن القيمة الاحتمالية (.Sig) المقابلة لاختبار "التباين الأحادي" داتهي"

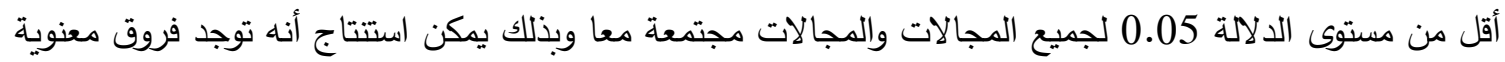
بين آراء المبحوثين حول ريادة الأعمال، وخريجي كليات التعليم التقني في قطاع غزة تعزى لـتغير المؤهل العلمي وتبين أنها لصالح حملة الدبلوم المتوسط. 3. لا توجد فروق معنوية بين آراء المبحوثين حول ريادة الأعمال، وخريجي كليات التعليم التقني في قطاع غزة تعزى لمتغير سنوات الخبرة

جدول (17): نتائج اختبار" التباين الأحادي " - سنوات الخبرة

\begin{tabular}{|c|c|c|c|c|c|c|}
\hline \multirow{2}{*}{ الاحتمالية } & \multirow{2}{*}{ قاخة } & \multicolumn{4}{|c|}{ المتوسطات } & \multirow[b]{2}{*}{ المجال } \\
\hline & & فأكثر $\quad 20$ & سنة 10-10 & $\begin{array}{l}\text { سنوات } 10-5 \\
\text { سنات }\end{array}$ & 5 5 & \\
\hline 0.564 & 0.681 & 6.81 & 8.10 & 7.71 & 7.57 & رأس المال الفكري \\
\hline 0.715 & 0.453 & 7.81 & 8.06 & 7.44 & 7.66 & الميزة التنافسية \\
\hline 0.690 & 0.489 & 7.06 & 8.09 & 7.64 & 7.59 & معايع المجالات \\
\hline
\end{tabular}

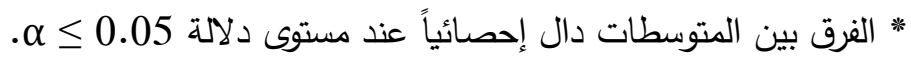

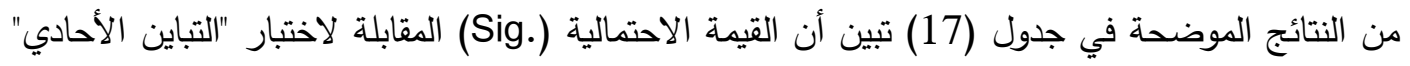

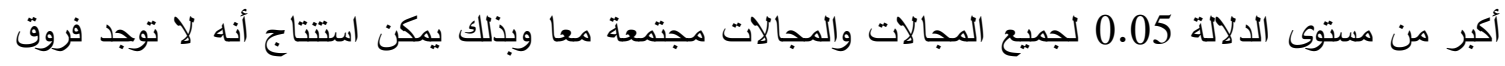

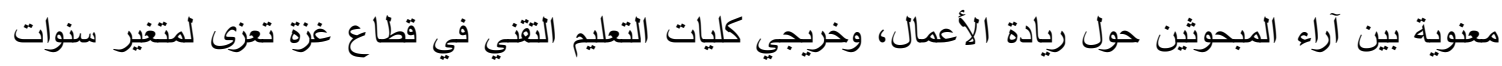
الخبرة. النتائج والتوصيات: أولا: النتائج: أ. النتائج الخاصة بواقع ريادة الأعمال في الكليات التقنية - اتضح أن هناك أثر لأبعاد ريادة الأعمال بنسبة تقدر بنحو 1.61. 81.

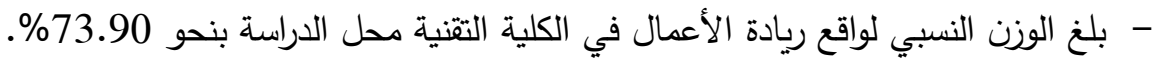


- اتضح أن تحمل المسئولية قد كان أعلى بعد وبوزن نسبي قدر بنحو 80.50\% من عوامل ريادة الأعمال في

وتبين أن لدى الكلية اهتمام مناسب بالمبدعين من الطلبة، حيث حصل مجال الابداع على وزن نسبي بنجو

\% 71.00

- ظهر أن الكلية تعمل على نشر ثقافة الريادة بين طلبتها، حيث حصل مجال الثقافة الريادية على وزن نسبي بنحو

- - اتضح أن الكلية تثجع طلبتها على ممارسة المخاطرة المحسوبة حيث حصل مجال درجة المخاطرة على وزن

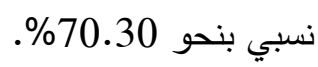

- تبين أن الكلية تثجع ريادة الأعمال في بيئتها بدرجة موافقة قدرت بنحو 73.90\%، ولكنها لم تقابل تطوير بيئة وواقع الكلية بنفس المستوى من حيث نوعية التدريب وصقل مهارات المتدرب وتحديث الأجهزة بشكل

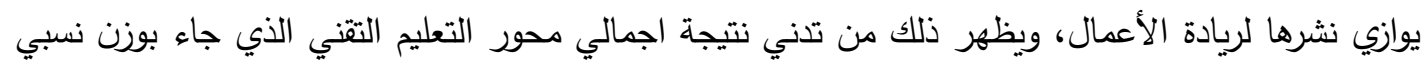
قدره 72.40\%، مقارنة بنتيجة بمحور ريادة الأعمال. ب. النتائج الخاصة بأبعاد التعليم والتدريب التقني:

- بلغ الوزن النسبي لأبعاد التعليم والتدريب التقني في الكلية التقنية محل الدراسة بنحو - اتضح أن مجال مهارة المدرب قد كان أعلى بعد بوزن نسبي قدر بنحو 73.90\% من أبعاد التعليم التقني في الكلية. - تبين أن هناك اهتمام مناسب في صقل مهارات المتدرب حيث حصل مجال المتدرب على وزن نسبي بنحو \%72.80 - ظهر أن الكلية تحرص على تطوير أجهزتها ووسائلها حيث حصل مجال الوسائل المستخدمة بالتدريب على

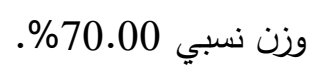

- اتضح أن الكلية لا تهتم في تطوير ممكنات التعليم والتدريب التقني بنفس القدر لنشرها لريادة الأعمال، حيث كانت النتيجة للريادة الأعمال 73.90\%، بينما نتيجة التعليم والتدريب التقني كانت بوزن نسبي أقل قدره

.$\% 72.40$

ثانيًا: التوصيات:

أ. التوصيات الخاصة بريادة الأعمال

- ضرورة الاستفادة من الأثر الكبير لريادة الأعمال في تعزيز التعليم والتدريب التقني بإعداد برامج تدعم ريادة الأعمال في مشاريع الطلبة التقنيين

- أن تعمل الكلية على زيادة نشر أفكار ريادة الأعمال بين طلابها بشكل يصل الى الى الفاعلية المرتفعة.

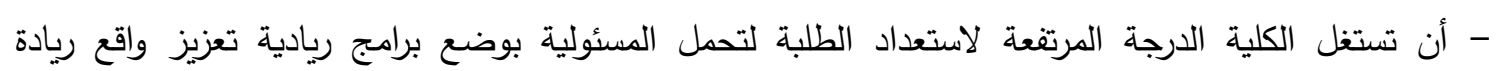
الأعمال. - أن تسعى الكلية لإنشاء مركز لرعاية الطلبة المبدعين وتعمل على توثيق مبادراتهم الابداعية بثكل يزيد من مكانتها.

- ضرورة وضع خطة مبرمجة تعزز من فاعلية نشر قيم وثقافة الريادة لدى الطلبة في الكلية. - أن تستغل الكلية الدرجة المرتفعة لاستعداد الطلبة لديها للمخاطرة المحسوبة في تعزيز واقع ريادة الأعمال. 
ب. التوصيات الخاصة بالتعليم والتدربب التقني - - ضرورة أن تخصص الكلية مزيد من الموازنات لرفع كفاءة عملية التدريب بأبعادها (المدرب، المتدرب، وأجهزة

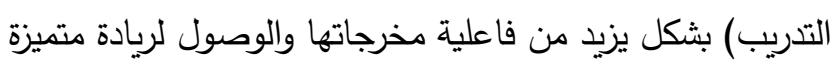
- أن تعمل الكلية على برامج تدريب نوعي وابتعاث خارجي للمدربين لديها لنقل أحدث تكنولوجيا ومهارات التدريب التقني.

- أن تحرص وتركز الكلية على صقل واكساب مهارات ومعارف ذات التكنولوجيات والتقنية العالية لخرجيها. - - ضرورة أن تعمل الكلية باستمرار على تطوير وسائل وأجهزة التدريب بشكل يناسب التطوير في بيئة وسوق

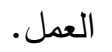
- كي تججح الكلية في تطبيق ريادة الأعمال على طلابها عليها أولاً رفع معدل تطوير ممكناتها وأهمها (المدرب، المتدرب، وأجهزة التدريب) بثكل يفوق النشر النظري لمفاهيم ريادة الأعمال.

المراجع أبو الثعر ، حنين. ( 2016 ). مدي توافر النية الريادية والعوامل المؤثرة فيها لدي طلبة الجامعات الحكومية في الأردن، (رسالة ماجستير غير منشورة)، كلية الاقتصاد والعلوم الإدارية، جامعة اليرموك.

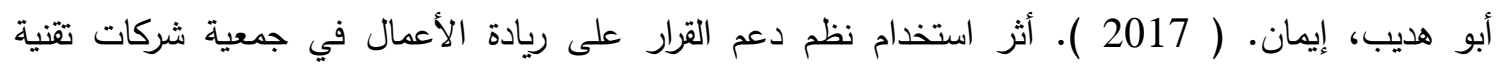
المعلومات والاتصالات (إنتاج) الأردن، (رسالة دكتوراه غير منشورة)، كلية الدراسات العليا، جامعة العلوم الإسلامية العالمية.

أبوعصبة، مي. (2005). مشكلات التعليم المهني في المدارس الثانوية المهنية الفلسطينية من وجهة نظر المعلمين

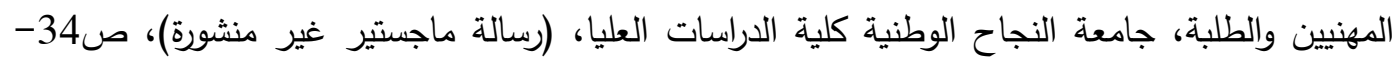

أحمد، نورا. (2013). واقع التعليم المهني في محافظة ديالى من وجهة نظر الهيأة التدريسي، مجلة الفتح كلية

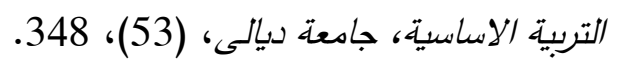
بدرخان، سوسن. (2014). اتجاهات طلبة الصف العاشر الأساسي في الأردن نحو الالتحاق بمجالات التعليم

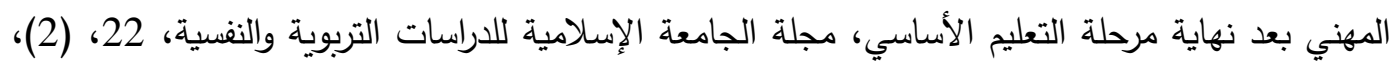
99 ص 65

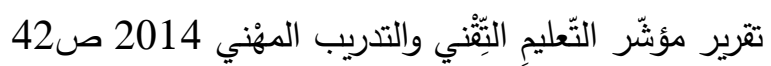
حامد، مهند، راثد فوزي، نحو سياسات لتعزيز الريادة بين الثباب في الضفة الغربية وقطاع غزة (د.ط)، رام الله

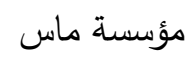
الحسيني، ف (2006). ادارة المشروعات الصغيرة مدخل استراتيجي للمنافسة مؤسنة الحلبي، شادي. (2012). واقع التعليم المهني والتقني ومشكلاته في الوطن العربي: دراسة حالة الجمهورية العربية

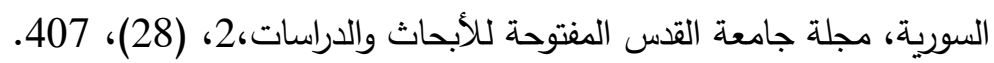
حماد، خليل، النخالة، سمية. (2018). مشكلات التعليم المهني في محافظات غزة كما يراها المعلمون، بحث مقدم الى مؤتمر التعليم التقني والمهني في فلسطين: واقع وتحديات وطموح المنعقد في الكلية الجامعية للعلوم

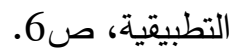


الحمالي، رشاد والعربي، هثام. ( 2016 ). واقع ثقافة ريادة الأعمال بجامعة حائل وآليات تفعيلها من وجهة نظر

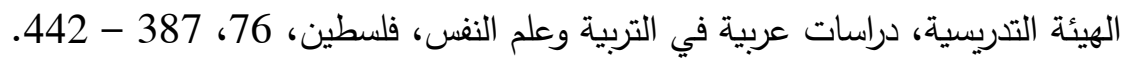
خربوطلي، عامر (2018). ريادة الأعمال وادارة المشروعات الصغيرة والمتوسطة من منشورات الجامعة الافتراضية

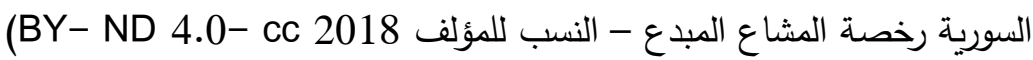
دياب، عبد الحميد. ( 2012 ). مدي تأثير الثقافة التنظيمية في نجاح ريادة الأعمال في الخطوط الجوية العربية السعودية بالتطبيق على موظفي الخدمات الفنية في مطار الملك عبد العزيز الدولي بمدينة جدة، المجلة العلمية للاقتصاد والتجارة، مصر 41 - 53

زيدان، عبد الرازق وخليل، عبد القادر • ( 2017 ). متطلبات تحقيق الريادة في القطاع المصرفي حالة بنك الفلاحة

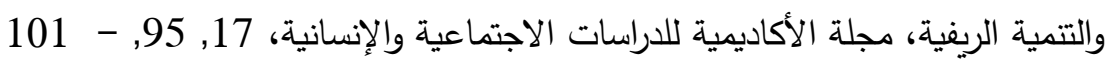

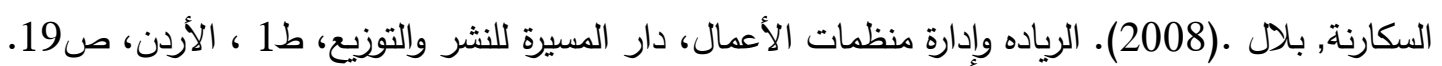

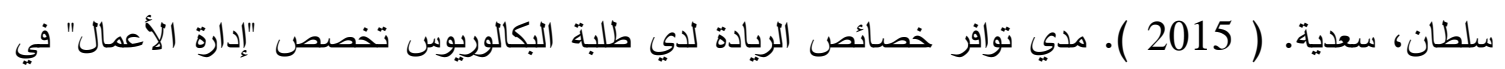
جامعات جنوب الضفة الغربية، أعمال مؤتمر "الريادة والإبداع في تطوير الأعمال الصغيرة"، الجامعة لإنة الإسلامية -غزة، فلسطين

السيد، لمياء وإبراهيم، إيمان. ( 2014 ). سياسات وبرامج التعليم الريادي وريادة الأعمال في ضوء خبرة كل

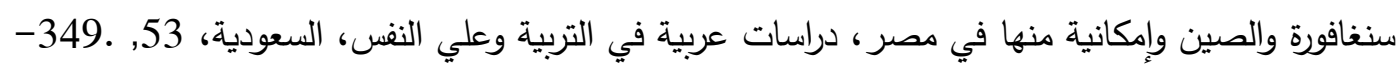

شحاته، صفاء. ( 2013 ). تتمية جدارات سوق العمل لدي المتعلمين في مؤسسات التعليم العالي من خلال

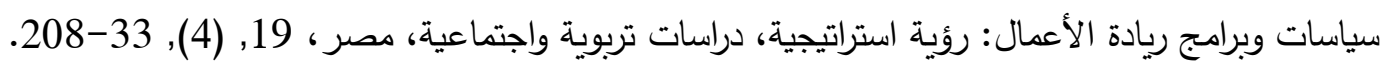

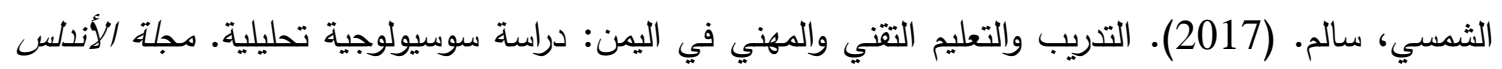

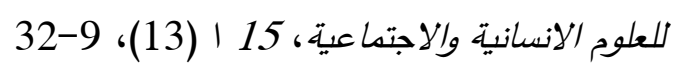

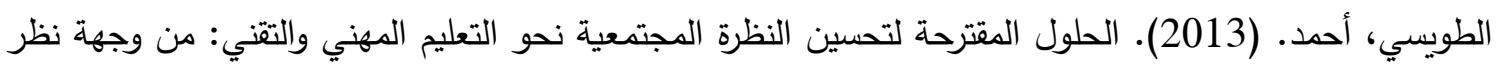
الخبراء في الأردن. دراسات العلوم التربوية، كلية العلوم التربوية، جامعة مؤتة، الأردن، 40، بادئ (2)، 1489 العاجز، فؤاد. (12-2018/10/13) مشكلات معلمي التعليم المهني والتقني في محافظات غزة وسبل التغلب عليها، بحث مقدم الى مؤتمر التعليم التتني والمهني في فلسطين: واقع وتحديات وطموح المنعقد في الكلية

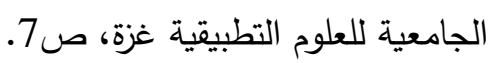
العاني، م, وآخرون. (....). ادارة المشروعات الصغيرة منظور ريادي تكنولوجي، الطبعة الاولى، دار صفاء للنشر والتوزيع، عمان.

عبد الله، جلال. (2012). مشكلات مخرجات التعليم الفني والتدريب المهني في بيئة العمل الصناعية بمحافظة

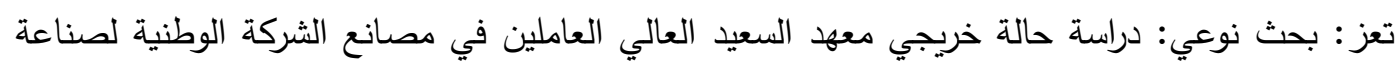

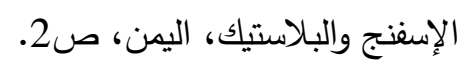

عبد الوهاب ايمان. (2018). مسارات التحول بمؤسسات التعليم الجامعي المصري نحو صيغة الجامعة الريادية

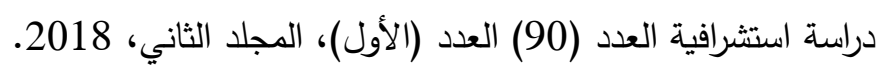

العبيدي، رأفت والجراح، أضواء. ( 2014 ). رأس المال الفكري في إطار متغيرات بيئة ريادة الأعمال: دراسة

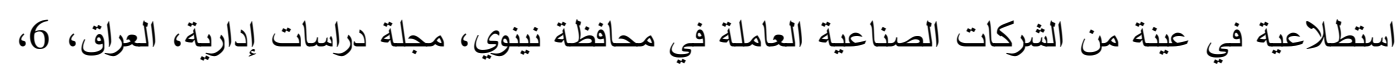

$$
.202-158
$$


العجايب، أمنة. ( 2017 ). أثر تمكين المرأة على نمو الأعمال الريادية في الأردن، رسالة ماجستير غير منشورة، كلية الأعمال، جامعة عمان العربية

العجوري. (2011). واقع برامج التدريب المهني ودورها في عملية التتمية وآليات تطويرها من وجهة نظر خريجي التدريب المهني في محافظة بيت لحم (رسالة ماجستير غير منشورة)، جامعة القدس. فلسطين.

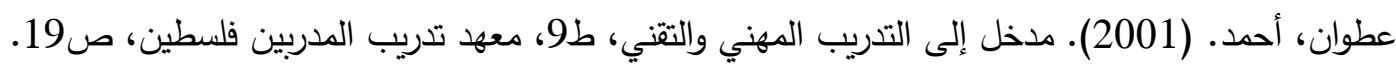

اللامي، النعيمي. (2003). الاتجاهات العالمية في إعداد المدربين في التعليم المهني، ط1, دار الكتب الوطنية،

$$
\text { بنغازي, صبع. }
$$

مبارك، م•(2009) :الريادة في الاعمال (المفاهيم والنماذج والمداخل العلمية) الطبعة الأولى، عالم الكتب

$$
\text { الحديث، عمان. }
$$

المحاريق، صخر • (2014). دور التعليم والتدريب المهني والتقني في التتمية المجتمعية المستدامة من وجهة نظر

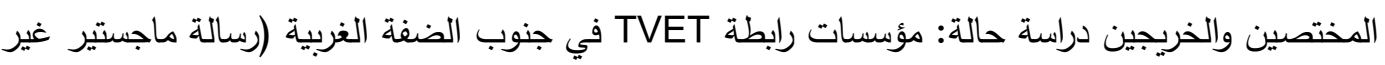

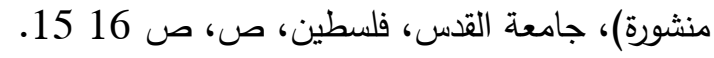

محمد، عوض الله ومحمود، أشرف. ( 2014 ). قياس مستوي ريادة الأعمال لدي طلاب جامعة الطائف ودور

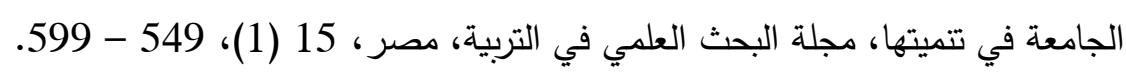

المخيزيم، حسام. ( 2017 ). واقع تتمية ثقافة ريادة الأعمال لطلاب جامعة الإمام محمد بن سعود الإسلامية،

(رسالة ماجستير غير منشورة)، كلية العلوم الاجتماعية، جامعة الإمام محمد بن سعود الإسلامية.

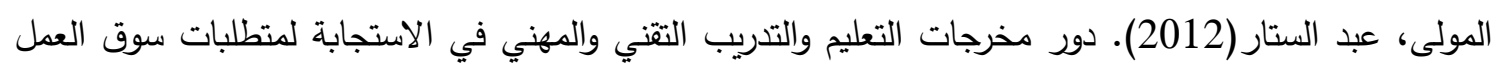

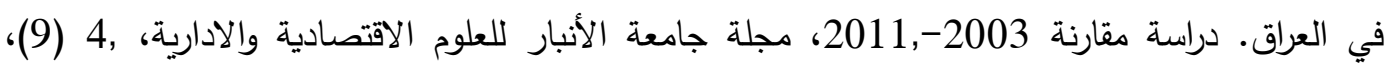

المومني، هنادة. ( 2016 ). دور الخصائص الريادية للعاملين في الجامعات في بناء الجامعة الريادية -دراسة

تطبيقية على الجامعات الأردنية الخاصة، مجلة دراسات، كلية العلوم الإدارية والمالية، جامعة البتراء.

$813-825$. (2) 43

\section{References}

Abdul Wahab, I. (2018). The Egyptian university transformational phase towards pioneering university. A future approach study, 2(90). (in Arabic)

Abdullah, J. (2012). Problems faced by technical and vocational graduates in the industrial field of Taiz governorate: A qualitative analysis of Al-Saeed Higher Institute graduates working in the factories of the National Sponge and Plastics Industry Company- Yemen. (in Arabic)

Abouasba, M. (2005). Problems of vocational education in Palestinian vocational secondary schools: Feedback of teachers and students [Unpublished master's thesis]. Graduate School, Al-Najah National University. (in Arabic)

Abu al-Chaar, H. (2016). Aspects of leadership spirit of students of Jordanian public universities [unpublished Master's thesis]. Faculty of Economics and Management Sciences, Yarmouk University. (in Arabic)

Abu Hadib, I. (2017). The impact of decisive strategies on entrepreneurship in ICT Companies [Unpublished Doctoral dissertation]. Graduate School, World Islamic University. (in Arabic) 
Ahmed, N. (2013). The reality of vocational education in Diyala Province: Feedback of teaching faculty members. Faculty of Basic Education, University of Diyala. AlFath Magazine, (53), 348. (in Arabic)

Al-Ajayeb, A. (2017). The impact of women' empowerment on the growth of leading business in Jordan [Unpublished Master's Thesis]. Business School, Arab University of Amman. (in Arabic)

Al-Ajess, F. (2018). Teachers problems and suggested solutions: The vocational and technical sector in Gaza governorates. Research submitted to the Conference on Technical and Vocational Education in Palestine: Reality, Challenges and Ambition held at the University College of Applied Sciences Gaza, p. 7. (in Arabic)

Al-Ajuri. (2011). The reality of vocational training programs, their evolution and their role on trainees' development: Point of view of graduates in Bethlehem Governorate [unpublished Master's thesis]. Al Quds University, Palestine. (in Arabic)

Al-Ani, M. et al. (n.d.). The management of small business from a technological perspective. Safaa Publishing and Distribution House, Amman (1st Ed.). (in Arabic)

Alareeni, B. (2018). The impact of firm-specific characteristics on earnings management: evidence from GCC countries. International Journal of Managerial and Financial Accounting, 10(2), 85-104. https://doi.org/10.1504/IJMFA.2018.091659

Alareeni, B. (2018). Does corporate governance influence earnings management in listed companies in Bahrain Bourse?. Journal of Asia Business Studies, 12(4), 551-570. https://doi.org/10.1108/JABS-06-2017-0082

Alareeni, B. (2019). The associations between audit firm attributes and audit qualityspecific indicators: A meta-analysis. Managerial Auditing Journal, 34(1), 6-43. https://doi.org/10.1108/MAJ-05-2017-1559

Alareeni, B., \& Branson, J. (2013). Predicting listed companies' failure in Jordan using Altman models: A case study. International Journal of Business and Management, 8(1), 113-126. https://doi.org/10.5539/ijbm.v8n1p113

Alcaraz, J., Hollander, R., \& Navarra, A. (2019). The business initiative for technical education (BITE): Creating shared value, boosting a country. Competitiveness Review: An International Business Journal, 29(1), 8-25. https://doi.org/10.1108/CR-06-2016-0033

Al-Halabi, S. (2012). Strenghths and weaknesses of vocational and technical education in the Arab world: A case study of Syria. The Journal of the Open University of Jerusalem for Research and Studies, 2(28), 407. (in Arabic)

Al-Hamali, R., \& Al-Arabi, H. (2016). Entrepreneurship cultural fact at Hail University and motivational aspects: Feedback of faculty members in Palestine. Arab Studies in Education and Psychology, 76, 387-442. (in Arabic)

Al-Lami, A. (2003). Global trends in the preparation of trainers in vocational education. National Book House, Benghazi, (1st Ed. p. 15). (in Arabic)

Al-Maharik, S. (2014). The role of vocational and technical education towards sustainable society from the point of view of graduate students: A case study [unpublished Master's thesis].

Al-Mawla, A.S. (2012). Matching technical and vocational graduating students to the need of the Iraqi labor market: Comparison study 2003-2011-Anbar University. Journal of Economics and Administrative Sciences, 4(9), 406. (in Arabic) 
Al-Moukhayzim, H. (2017). The reality of developing students' entrepreneurial culture in the Imam Mohammed Bin Saud Islamic University [Unpublished master's thesis]. Faculty of Social Sciences, Imam Mohammed Bin Saud Islamic University. (in Arabic)

Al-Moumni, H. (2016). Pioneering role of university staff towards the construction of a leading university: Case study of private universities in Jordan. Faculty of Administrative and Financial Sciences, Petra University. Journal of Studies, 43(2), 825-813. (in Arabic)

Al-Obaidi, R., \& Al-Jarah, A. (2014). Intellectual capital in changing entrepreneurial environment: A case study of a sample of industrial companies operating in The Province of Ninoweh, Iraq. Journal of Management Studies, 6(12),158 -202. (in Arabic)

Al-Sakrana, B. (2008). Leadership and organizational management. Al-Masra Publishing and Distribution House, Jordan ( $1^{\text {st }}$ Ed. p. 19). (in Arabic)

Al-Sayed, L., \& Ibrahim, I. (2014). Entrepreneurship policies and educational programs in Singapore and China and potential applicability in Egypt. Arab Studies in Education and Self-Awareness, 53, 349-275, Saudi Arabia. (in Arabic)

Al-Shami, S. (2017). Technical and vocational education in Yemen: Sociological and analytical study. Al-Andalus Journal of Humanities and Social Sciences, 15(13), 932. (in Arabic)

Al-Tweisi, A. (2013). Proposed solutions to improve community perception of vocational and technical education: Feedback of Jordanian experts. Educational Science Studies, 40(2), 1489. Faculty of Educational Sciences, Moata University, Jordan. (in Arabic)

Al-Tweisi, A. (2013). Proposed solutions to societal perception of vocational and technical education: Feedback from Jordanian experts. Educational Science studies ,40, (2), 1489. Faculty of Educational Sciences, Moata University, Jordan. (in Arabic)

Anke, B., \& Agnes, D. (2019). Work-based Learning as a Pathway to competence-based education. Publisher: Federal Institute for Vocational Education and Training $\left(1^{\text {st }}\right.$ Ed.), Robert-Schuman-Platz 3 D-53175 Bonn. p13

Atwan, A. (2001). Introduction to vocational and technical training. Palestine Training Institute, ( $9^{\text {th }}$ Ed.p.19). (in Arabic)

Badrkhan, S. (2014). $10^{\text {th }}$ grade Jordanian students' enrollment trends to vocational education. Islamic University of Educational and Psychological Studies, 22(2), 6599. (in Arabic)

Chodasová, Z., Tekulová, Z., Hl’ušková, L., \& Jamrichová, S. (2015). Education of students and graduates of technical schools for contemporary requirements of practice. Procedia-Social and Behavioral Sciences, 174, 3170-3177. https://doi.org/10.1016/j.sbspro.2015.01.1058

Diab, A. (2012). The impact of organizational culture on the success of entrepreneurship in the Saudi Arabia Airlines sector: A survey for employees at King Abdulaziz International Airport in Jeddah. Scientific Journal of Economics and Trade, Egypt, 41-53. (In Arabic)

Din, B. H., Anuar, A. R., \& Usman, M. (2016). The effectiveness of the entrepreneurship education program in upgrading entrepreneurial skills among public university students. Procedia-Social and Behavioral Sciences, 224, 117123. https://doi.org/10.1016/j.sbspro.2016.05.413 
Duman, L., Bedük, A., Köylüoğlu, A. S., \& Ay, K. (2015). Entrepreneurship culture at SMEs: A case study in konya. Procedia-social and behavioral sciences, 207, 492501. https://doi.org/10.1016/j.sbspro.2015.10.119

European Commission. (2015). Agenda for New Skills and Jobs "Entrepreneurial Skills" [ Report]. European commission.

Galvão, A. R., Marques, C. S., Ferreira, J. J., \& Braga, V. (2020). Stakeholders' role in entrepreneurship education and training programmes with impacts on regional development. Journal of Rural Studies, 74, 169-179. https://doi.org/10.1016/j.jrurstud.2020.01.013

Hamed, M., \& Rashid F. (2006). Towards policies to promote leadership among young people in the West Bank and Gaza Strip. Ramallah Mas Foundation Al-Husayni. Small business management: Competitive advantage. (in Arabic)

Hammad, K.A.S. (2018). Problems of vocational education in the Governorate of Gaza: Feedback of teachers. Research presented to the Conference on Technical and Vocational Education in Palestine: Reality, challenges, and ambition. The University of Applied Sciences. (in Arabic)

Kharbutali, A. (2018). Entrepreneurship and SME Management. The Syrian Virtual University- Creative Commons License - Proportions by BY-ND 4.0-CC. (in Arabic)

Mahajan, P. T., \& Golahit, S. B. (2017). Management of people mix: An essential criteria for technical education. Online Submission, 8(3), 523-530. https://doi.org/10.5958/2321-5763.2017.00084.1

Mubarak, M. (2009). Leading entrepreneurs (Concepts and models). Modern Book World, Amman (1st Ed). (in Arabic)

Muhammad, A., \& Mahmoud, A. (2014). Measuring the level of students' entrepreneurship at Taif University and impact of the university role. Journal of Scientific Research in Education, Egypt, 15 (1), 549-599. (in Arabic)

Odo, J. U., Okafor, W. C., Odo, A. L., Ejikeugwu, L. N., \& Ugwuoke, C. N. (2017). Technical education-The key to sustainable technological development. Universal Journal of Educational Research, 5(11), 1878-1884. https://doi.org/10.13189/ujer.2017.051104

Rosen, R., Visher, M., \& Beal, K. (2018). Career and technical education: Current policy, prominent programs, and evidence. MDRC.

Shahatah, S. (2013). Developing the labor market merits for higher education learners through entrepreneurial policies and programs: Strategic vision, educational and social studies. Journal of Scientific Research in Education, Egypt,19(4), 208-33. (in Arabic)

Sultan, S. (2015). Entrepreneurial characteristics of college students and the link to study Business Administration at southern West Bank universities. Conference "Entrepreneurship and Creativity in small business development". Islamic University - Gaza, Palestine. (in Arabic)

Technical and Vocational education and Training. (2014). TVET Index Report. (in Arabic)

Zidan, A.R., \& Khalil, A.K. (2017). Requirements for achieving leadership in the banking sector: The case of the bank of Agriculture and Rural Development. Journal of the Academy of Social and Humanitarian Studies, 17, 95-101. (in Arabic) 